\title{
Patient selection in the presence of regulatory oversight based on healthcare report cards of providers: the case of organ transplantation
}

\author{
Mariétou H. Ouayogodé ${ }^{1}$ (D) $\cdot$ Kurt E. Schnier ${ }^{2}$ \\ Received: 4 December 2019 / Accepted: 27 October 2020 / Published online: 8 January 2021 \\ (C) Springer Science+Business Media, LLC, part of Springer Nature 2021
}

\begin{abstract}
Many healthcare report cards provide information to consumers but do not represent a constraint on the behavior of healthcare providers. This is not the case with the report cards utilized in kidney transplantation. These report cards became more salient and binding, with additional oversight, in 2007 under the Centers for Medicare and Medicaid Services Conditions of Participation. This research investigates whether the additional oversight based on report card outcomes influences patient selection via waiting-list registrations at transplant centers that meet regulatory standards. Using data from a national registry of kidney transplant candidates from 2003 through 2010, we apply a before-and-after estimation strategy that isolates the impact of a binding report card. A sorting equilibrium model is employed to account for center-level heterogeneity and the presence of congestion/agglomeration effects and the results are compared to a conditional logit specification. Our results indicate that patient waiting-list registrations change in response to the quality information similarly on average if there is additional regulation or not. We also find evidence of congestion effects when spatial choice sets are smaller: new patient registrations are less likely to occur at a center with a long waiting list when fewer options are available.
\end{abstract}

Keywords Healthcare report cards $\cdot$ Regulation $\cdot$ Competition $\cdot$ Transplantation $\cdot$ Patient selection

JEL classifications D03 $\cdot$ I18 $\cdot$ R41

\section{Highlights}

- Conditional logit and sorting equilibrium models for transplant center choice are used.

- The impact of the binding report cards, due to additional regulatory oversight, in kidney transplantation on transplant center choice is isolated.

Mariétou H. Ouayogodé

Marietou.Ouayogode@wisc.edu

Kurt E. Schnier

Kschnier@Ucmerced.edu

1 School of Medicine and Public Health, Department of Population Health Sciences, University of Wisconsin-Madison, 610 Walnut St, Madison, WI 53726, USA

2 School of Social Sciences, Humanities and Arts, University of California, Merced, 5200 North Lake Road, Merced, CA 95343, USA
- Patient waiting-list registrations change in response to the quality information similarly if in presence or absence of binding regulation.

- Congestion effects are estimated when spatial choice sets are smaller.

\section{Introduction}

The use of report cards in healthcare is targeted at addressing informational asymmetries and increasing the accountability of providers and stimulating improvements in quality [1]. Most of these report cards rate providers using objective measures of quality, such as mortality rates. This information may then be used by patients, consumers of healthcare, to determine the provider that best suits their healthcare needs. For many of these report cards the primary incentive that a provider has to increase their quality, and therefore their report-card rating, is the potential increase in the number of services they provide when consumers select them over another provider. 
Report cards issued by the Scientific Registry of Transplant Recipients (SRTR) - publicly reported since 2002, included quality information based on 1-year patient and graft survival statistics for transplant centers - incentivize patients and their referring physicians to select higher quality centers. Starting on June 28, 2007, the Centers for Medicare and Medicaid Services (CMS) took a regulatory approach by using these two report-card quality measures to determine whether transplant centers are compliant with quality standards, Conditions of Participation (CoPs) [2]. Non-compliance with the CMS CoPs may result in regulatory review and the potential loss of transplant center funding. Therefore, the report cards issued following the CMS regulation represent a regulatory-binding constraint on a transplant center's activities.

Registration on a center's waiting list happens as a result of a multi-step selection process. First, patients with end-stage renal disease (ESRD) show interest and have no medical absolute contraindication to transplantation $[3,4]$. Second, the patients obtain a referral initiated by them, their physician (nephrologist), or other dialysis facility personnel. Third, they are evaluated at the transplant center of choice using a physical examination and blood tests to assess organ function and general state of health and registration on the center's waiting list will depend on center-specific selection criteria. For example, evaluation outcomes for the patients being considered for wait-listing are "too well for consideration", "not a candidate", "being a suitable candidate for organ transplantation" [3, 4]. Many ESRD patients do not get to pass the evaluation process. Sullivan et al. [5] found in a controlled trial in 2009 that $18 \%$ of intervention participants and $8 \%$ of those in the control group completed all transplant process steps and were added to the deceased transplant waiting list. Among reasons recorded for failing to complete the transplantation process, medical limitations such as acute and chronic conditions and patient reluctance were the most common, whereas financial concerns were the least common [5]. A more recent study found financial concerns to be more prevalent among referred patients not following through with getting a transplantation evaluation [6]. Racial/ethnic disparities have been found in access to the initial transplantation evaluation, likely due to lack of referrals by providers, and lack of patient's knowledge about evaluation benefits or transplantation process [7].

Several mitigating factors can influence changes in patient sorting and waiting list rates across transplant centers over time. Sorting refers to correlations between patients' characteristics and center attributes that occur when patients locate themselves in the transplant center market space. Mitigating factors influencing patient sorting include changes in type of patient's insurance coverage, nephrologist or dialysis center referral patterns, patient preferences, or the center being more selective on the type of patients they register on their waiting list. Insurance providers may use program-specific reports data to identify higher quality transplant programs for contracting [8-10], which may increase registrations at centers with superior patient survival rates and make centers with lower survival rates less competitive. Nonetheless, because Medicare is the primary insurance used by ESRD patients [11], patients may exercise greater flexibility in choosing transplant centers than would patients with disease conditions where private insurance coverage is more prevalent. Dialysis facilities and physicians are more likely better informed than transplant candidates on quality of transplant centers, which may influence referral patterns. Nonetheless, prior studies of cardiovascular surgeons in Pennsylvania, for example, found that quality report card outcomes for coronary artery bypass graft (CABG) had little impact on their referral patterns [12]. Moreover, low or high quality designation for providers and the amount of transplant education patients receive from their providers (e.g. dialysis centers, clinicians) may impact waiting list rates [13-15]. Waiting list prospects may also be reduced by not having a transplant center nearby or living in an area with lower socio-economic status $[16,17]$. The SRTR report cards may therefore influence a patient's registration on a center's waiting list as those in need of a kidney transplant sort across centers according to their physician, insurance, own preferences for healthcare provision, their characteristics, and center-level attributes and selection processes. Furthermore, the aggregation of these patient registrations may impact volume of transplants conducted at a center and queuing on center's waiting list [18].

Because the CMS CoPs are not included in programspecific report cards, patients may be less aware of the additional CMS oversight over and above the information available in report cards. Additionally, from the patient's perspective, performance of a transplant center post-transplant or graft survival for example may have less of an impact on the patient's choice of a center if getting a transplant is more important for survival and quality of life than what occurs after transplant [8]. Consequently, the potential impact of CMS additional oversight may be muted. However, the CMS CoPs may have an important impact on patient volume through increased risk aversion of transplant centers, potentially limiting access to care for some patients (e.g. those with some medical conditions) [19]. Low performance on program-specific report card outcomes which influences reputation and financial health of providers [20] may increase risk aversion of centers and be associated with problematic behavior of selecting patients who may help achieve superior quality performance [21, 22]. An informal survey of transplant management personnel at a national meeting in 2009, post-CMS CoPs, showed that personnel from low-performing centers were more likely to indicate that they increased selection criteria of candidates, donors, and clinical protocols [23]. Overall, the impact of the CMS CoPs, making report cards regulatory binding, on patient volume remains unclear and should be assessed empirically. Knowledge about the impact 
of the CMS regulation on patient sorting will increase our understanding of how report cards and additional oversight influence competition among healthcare providers and patient selection. In addition, it may inform the future development of healthcare report card systems and regulatory oversight. Our research addresses this gap and focuses on how this regulation affects patient volume.

In this analysis, we present a qualitative choice model for the selection of patients on the deceased-donor waiting list between 2003 and 2010. We utilize a before-and-after specification to estimate those impacts induced by additional oversight, post-CMS CoPs. Notwithstanding the complexity of the waiting-list registration process aforementioned, we present the patient as the decision maker when empirically analyzing patient registrations, for simplicity. We estimate the regulation effects using both a conditional logit specification [24] as well as a sorting equilibrium model $[25,26]$ that controls for center-level heterogeneity and endogenous sorting of patients. A sorting equilibrium model of transplant center choice provides a framework for understanding the interactions among patients, transplant center markets, and spatially delineated attributes. In this model, individual patients make choices and maximize their total satisfaction from making those choices based on their expectations about the decisions that other patients will make. In equilibrium, those expectations are validated by other patients' actual behavior. Sorting equilibrium models use the properties of market equilibria in addition to information on patients' sorting behavior to infer structural parameters that describe heterogeneity in preferences and selection. Such models reflect the information available to participating agents, their constraints and the implications associated with their combined choices [27]. The sorting equilibrium model employed in our analysis will also measure the level of congestion or agglomeration present which will inform on how and to what extent on-site experience affects sorting of patients across centers. Using existing evidence from the hospital choice literature [28], we hypothesize that the regulatory environment, centers' attributes, and individual characteristics also matter in access to transplantation.

\section{Literature review}

Economic theory predicts that in a market with controlled prices, quality is positively correlated with the price level [29]. In the case of organ transplantation, the pricing mechanism used to sort across quality is not preserved because the price of procedures is relatively fixed with organ procurement being regulated by the 1984 National Organ Transplant Act [30]. A transplant center's motive to increase quality (i.e. report card rating) is to attract patients and increase their volume as well as to meet the CMS CoPs. The impact that the information conveyed in the report cards has on the center's level of quality depends on both the quality of the information provided and the costs the center bears trying to increase quality $[31,32]$.

Although no study to our knowledge has investigated the impact of the CMS CoPs on patient sorting to date, existing evidence of the impact of provider report cards on health quality or selection of providers is mixed [12, 22, 33-47]. Disparity in these results may be due to nonrandom sorting of patients across providers that in turn determines providers' measure of quality [48]. Moreover, the type of quality measured may affect the role it has on the patient's selection process [35]. Furthermore, patients may possess a high degree of "market based" learning, where they learned from sources separate from report cards [42]. Report cards may have no impact if they conformed to prior beliefs of quality, but if they differed from these beliefs they would influence provider selection, albeit more negatively than positively [46].

The distance one travels to acquire marginal additions in quality is another important factor in a patient's response to quality information [36, 37] as the impact of the reports may only be relative to providers available within a reasonable distance of a patient. For example, in their study on the impact of kidney transplant centers' report cards on patient demand prior to the CMS regulation, Howard, Kaplan [36] restricted the choice set to a 200-mile buffer for patients needing kidney transplantation and found that a one standard deviation increase in a center's graft survival rate decreased the center's enrollments by $6 \%$. Overall, findings in the existing literature on report cards suggest that the decision environment and the informed nature of the decision agent may play a key role.

Our research differs from Howard, Kaplan [36] in two very important ways. First, we investigate the impact of the CMS CoPs, making report cards regulatory-binding. Second, we control for the impact that a patient's registration may have on other patients as well as center-level heterogeneity. This latter point of differentiation also allows us to investigate whether or not the sorting process generates congestion or agglomeration effects at centers. This study was reviewed and approved by the Institutional Review Board of the University of California-Merced.

\section{Regulatory background}

The report cards used in organ transplantation are published by the SRTR and issued every six months, at the end of June and December. These reports provide detailed information on transplant centers' performance relative to risk-adjusted expected values. The primary measures of quality we are interested in are the transplant center's 1-year graft and patient survival rates because these measures are monitored under the CMS CoP regulations [2]. These rates are calculated using transplants undergone during a two-and-half-year rolling 
cohorts, regardless of when the transplant recipients registered on the waiting list, at each transplant center. For instance the report issued on June 30,2007, just following the adoption of the CMS CoPs, was based on quality measures of transplants undergone from January 1, 2004 through June 30, 2006. This feature is important in our analysis as these measures are derived from lagged center performance and are therefore not endogenous variables in our empirical model.

In addition to detailed information reported on a center's activity and post-transplant graft and patient survival outcomes, a report card would compare the center's observed survival outcome to what would be expected using similar patients at the national level. Patients would be able to explicitly see if a center's survival outcomes are "significantly lower", "not statistically different", or "significantly higher" than the expected survival outcomes based on similar patients. In recent years, the SRTR started providing a table synthesizing information available on report cards for all active centers' patient survival outcomes, including information on the number of transplant candidates, number of transplants, and patient survival outcome comparison between the center's outcomes and what would be expected using similar patients at the national level for patients who had a deceased donor or a living donor transplantation and by age category. In December 2016, the SRTR moved from a 3-tier to a 5-tier rating summary of 1-year post transplantation survival outcomes with tier 1 being the worst and tier 5 being the best, to further differentiate program performance and reduce variance in outcomes between transplant programs within the same tier [8].

The 2007 CMS CoPs use a three-trigger system. A center is deemed non-compliant if its observed survival rates for 1-year graft or patient survival are lower than expected and the following three conditions are met: (1) the difference between the number of observed $(O)$ events (patient deaths or graft failures) and the number of expected $(E)$ events is greater than 3 $[O-E>3]$; (2) the ratio of the number of observed events to the number of expected events is greater than $1.5[O / E>1.5]$; and (3) the one-sided $p$ value, based on an exact Poisson test for the difference between the observed and expected events, is less than 0.05 [ $p$ value $<0.05]$ [2].

The CMS CoP standards are binding for kidney transplant centers seeking (re)certification for Medicare coverage. The CoPs require that a center hit all three triggers on any quality measure at least twice within a three-year period in order for CMS to initiate a formal review. However, we have elected to use the presence of all three triggers on a single report as a signal of lower quality. Moreover, the CMS regulation imposes an additional constraint associated with non-compliance, the risk for Medicare de-certification (i.e. loss of insurance contract) of a transplant center. Transplant programs with poor report cards and not in compliance with the CoPs may be subject to an audit which may lead to probation, suspension, or program closure due to repeated low performance. In practice, though no program has been de-certified and completely closed during the study period. Centers deemed noncompliant are required to take corrective actions to improve their performance and may be formally reviewed by CMS. Non-compliant centers may also have to inform their waiting list patients about their performance, providing them with more quality information. However, this would not be captured in our data and analyses because we are only modeling the patients' initial decision to register at a given center and not transfer decisions. The fact that no program has been forced to close weakens the binding nature of the regulation but the costly quality improvement strategies required to avoid decertification make report cards following the CoPs the most binding, in use within the healthcare sector.

\section{Empirical model}

This study seeks to determine whether or not the regulatory binding nature of the report cards utilized within organ transplantation impacts patient sorting beyond the influence of a traditional healthcare report card. We employ a before-andafter estimation strategy imbedded in a random utility model [24] of a patient's decision regarding which center they choose to be listed at to receive a kidney transplant. We define $U_{i j t}$ as the utility (i.e. total satisfaction) that patient $i$ derives from selecting transplant center $j$ (on day $d$ ) in time period $t$, where the utility function can be represented by the following function:

$U_{i j t}=\delta_{j t}+X_{i j}^{\prime} \beta+Z_{i j t}^{\prime} \gamma+\varepsilon_{i j t}$,

and

$\delta_{j t}=W_{j t}^{\prime} \theta+\alpha \rho_{j t}+\mu_{j t}$.

The matrix $X_{i j}$ contains time-invariant information that influences the probability that patient $i$ will select transplant center $j$. The matrix $Z_{i j t}$ includes time-varying information that influences the probability that a patient $i$ will select transplant center $j$ (on day $d$ ) within period $t$ and $\varepsilon_{i j t}$ is the unobserved portion of $U_{i j t}$ that is assumed to be independent and identically distributed (i.i.d.) extreme value. The time period $t$ is defined as a 6-month period to align with the SRTR biannual report cards. For ease of presentation, we do not add the additional day time dimension (i.e $d$ ) in the equation and will refer to $t$ as the time dimension in the rest of the study.

The alternative and time specific constant, $\delta_{j t}$, captures center-specific measures of heterogeneity including centerlevel capability and practice patterns within period $t$ influencing the sorting behavior of patients across transplant centers in the given time period [26, 27, 49-51]. Capturing unobserved 
heterogeneity has been illustrated to be an important factor in the selection of a healthcare provider [41]. The matrix $W_{j t}$ comprises center and time-specific information that influences the value of $\delta_{j t}$. The parameter $\rho_{j t}$ is the share of patients that have selected and have been registered at transplant center $j$ in time period $t$. The associated coefficient $\alpha$ captures the degree of congestion or agglomeration (popularity). The number of patients at a center may signal popularity and interact positively with perception of the center's quality and performance, making the center more attractive to new patients. However, it may also suggest congestion with "overcrowding" and potential lack of flexibility in care. Waiting time for patients registered on a center's waiting list may not be entirely based on the number of people currently listed at that center but also depends on the number of people registered at other centers within the same organ donation service area. Additionally, the size of the waiting list and wait time at a center may be influenced by the center's policies on listing statuses of patients. Some centers may list patients less seriously ill or with less urgent needs for transplantation much earlier in the course of their illness than others. Therefore, a patient's waiting time may be influenced by 1) their own status, 2) the number of patients already registered at their center and the severity of these registered patients' illness and transplantation need urgency, 3) policies at their centers, and 4) and patients registered at other centers within the same organ donation area. Therefore, $\alpha$ would measure congestion/agglomeration directly at the center of choice and indirectly at other centers within the local donation area. For simplicity, we consider $\alpha$ to represent congestion/agglomeration at the center selected. Congestion is an important center attribute and a rationing device - where preferences exhibit a negative effect. It creates a negative externality (i.e. cost) on an individual [52]. Congestion could, therefore, occur with only a few people choosing a particular transplant center. We hypothesize that congestion would reduce the value of a center. Lastly, $\mu_{j t}$ is a normally distributed error structure.

The probability that patient $i$ will select and be registered at transplant center $j$ (on any day $d$ ) in period $t$ can be written as

$P_{i j t}=\frac{\exp \left(\delta_{j t}+X_{i j}^{\prime} \beta+Z_{i j t}^{\prime} \gamma\right)}{\sum_{k=1}^{K} \exp \left(\delta_{k t}+X_{i k}^{\prime} \beta+Z_{i k t}^{\prime} \gamma\right)}$

where $K$ represents the number of transplant centers.

From Eq. (3) the predicted share of patients that will be registered at transplant center $j$ in period $t$ can be determined as follows:

$\rho_{j t}^{\text {Pred }}\left(\delta_{j t}, \beta, \gamma\right)=\frac{1}{M} \sum_{i=1}^{M} P_{i j t}\left(\delta_{j t}, \beta, \gamma\right)$

where $M$ is the total number of patients. The maximum likelihood estimates $\widehat{\delta}, \widehat{\beta}$ and $\widehat{\gamma}$ are obtained from the following optimization [26],

$\max _{(\delta, \beta, \gamma)} L\left(\delta, \beta, \gamma \mid X_{i j}, Z_{i j t}\right)=\prod_{i=1}^{M} \prod_{j=1}^{N} \prod_{t=1}^{T}\left(P_{i j t}\right)^{C_{i j t}}$

subject to,

$\rho_{j t}^{A c t}=\frac{1}{M} \sum_{i=1}^{M} P_{i j t}\left(\delta_{j t}, \beta, \gamma\right)$

where, $C_{i j t}$ takes the value of one if patient $i$ registers at transplant center $j$ in period $t$ and $\rho_{j t}^{A c t}$ is the actual observed share of patients that registered at transplant center $j$ in period $t$ as revealed in the data. The maximum likelihood estimates are generated iteratively. Conditional on a value for $\beta$ and $\gamma$, an estimate of $\delta_{j t}$ is obtained that preserves the observed sorting behavior of patients, $\rho_{j t}^{\text {Act }}$.

To obtain estimates for $\delta_{j t}$, we employ the contraction mapping method, a method for construction of solutions of nonlinear equations, developed by Berry [51]. Denoting $l$ as the $l^{\text {th }}$ iteration of the likelihood function, the $(l+1)$ value for $\delta_{j t}$ is captured by Berry [51],

$\widehat{\delta}_{j t}^{l+1}=\widehat{\delta}_{j t}^{l}-\ln \left[\rho_{j t}^{\text {Act }}-\rho_{j t}^{P r e d}\left(\widehat{\delta}_{j t}^{l}, \widehat{\beta}^{l}, \widehat{\gamma}^{l}\right)\right]$

This contraction mapping ensures that for any value of $\beta$ and $\gamma$ the parameter estimates for $\widehat{\delta}_{j t}$ preserve the observed sorting behavior captured by $\rho_{j t}^{\text {Act }}$. After obtaining the final parameter estimates for $\widehat{\delta}_{j t}$, we can estimate $\theta$ and $\alpha$ via an instrumental variables regression. In that regression, the observed share of patients registering at transplant center $j$ in period $t$ will be instrumented for because it is an endogenous variable in the estimation routine. Endogeneity ensues from the mechanical correlation - resulting from the specification of the model - between the expected probability of all candidates choosing a particular center alternative and the unobservable attributes of that alternative through equilibrium sorting [53]. Consequently, more attractive centers with a higher baseline utility will be expected to have more desirable unobserved characteristics.

We use an instrumental variables approach following Timmins, Murdock [53]. In this model, patients are assumed to have rational expectations about other patients' behavior. This assumption implies a constant vector of expected shares, $\rho_{j t}^{\text {Pred }}$ across all individuals. Therefore, the parameter estimates resulting from the sorting equilibrium model are consistent with Nash Equilibrium sorting behaviors, where no individual would benefit from changing their initial choice. 
We estimate our model using both a conditional logit specification and the sorting equilibrium model outlined above. The conditional logit model is specified as follows,

$$
U_{i j t}=X_{i j}^{\prime} \tau+V_{j t}^{\prime} \vartheta+Z_{i j t}^{\prime} \varphi+\varepsilon_{i j t} .
$$

The primary difference between the two models is that the conditional logit model assumes $\delta_{j t}=0$ or that both $\alpha=0$ and $\mu_{j t}=0$ if $W_{j t}$ is contained in Eq. (1). Although both $W_{j t}$ (in Eq. (2)) and $V_{j t}$ (in Eq. (8)) capture site and time-specific information, the number of observations contained in both matrices are different. The size of $V_{j t}$ is determined by the number of patient registrations observed, whereas $W_{j t}$ is determined by the dimensions of $\delta_{j t}$. In our results section, we partition the models based on the two specifications. Fundamentally, the conditional logit model ignores the site and time-specific heterogeneity that may result either from the sorting behavior of patients across centers or from factors that arise within the center. If patients were indifferent about transplant programs' characteristics but were only concerned about getting on any waiting list for kidney transplantation, and registration eligibility criteria were uniform across all centers, their utility would not be affected by center-specific unobserved heterogeneity, and both the sorting equilibrium and the conditional logit models would provide similar results. However, if such characteristics mattered in the decision-making process, they would need to be accounted for in our estimation because a basic conditional logit model would produce biased estimates. Presenting both the conditional logit and the sorting equilibrium models would therefore inform on the importance of controlling for spatial heterogeneity in the choice set.

As one of the primary determinants of patient's selection of healthcare providers $[28,54,55]$ distance, Dist $_{i j}$, is the sole variable included in $X_{i j}$ and we use two different distance buffers to investigate the robustness of our results to the assumed distance traveled. Distance has an effect on travel time to a center, and time itself is a very important determinant of organ quality. Kidneys can only be preserved for up to 48 hours outside a human body [56]. Consequently, patients often register at transplant centers that are in proximity to their residence. Furthermore, investigating "distance" is consequential because most patients, while awaiting transplantation - which can take years - are still undergoing dialysis treatment. Although we are not modeling them in this analysis, we realize that there are non-medical costs including travel costs to and from the transplant center before and after surgery as well as food, lodging, child care, or potential wages lost for workers, associated with the entire process. Distance, therefore, serves as a proxy for both pecuniary and non-pecuniary costs in the decision-making process.

In one specification, we consider only centers within the ninetieth percentile for the distribution of distances traveled to transplant centers, and in another, we use centers within the ninety-fifth percentile for distances traveled. In the appendix, we investigate the robustness of our results using the seventyfifth percentile of distances traveled.

Within the $Z_{i j t}$ matrix, we include nine different covariate controls: Age $e_{i j t}$, White $_{i j t}$, Black $_{i j t}$, Female $_{i j t}, B I_{i j t}, E C D_{i j t}$, HighSens $_{i j t}$, Diab $i j t$, and Donations $s_{i j t}$. The matrix $Z_{i j t}$ is constructed based on patients' registration dates, hence the additional subscript $i$. The variables White $e_{i j t}$, Black $_{i j t}$, and Female $_{i j t}$ indicate the percentage of patients that are either white, black, or female, respectively, and the variables $A g e_{i j t}$ and $B M I_{i j t}$ indicate the average age and body mass index of patients, respectively, at transplant center $j$ on the date (month, day, year) that patient $i$ is considering to be listed at in time period $t$. Race ethnicity may be an important factor in a patient's utility because organ compatibility is correlated with one's ethnicity. Age and BMI may also be important factors in a patient's utility because advanced age and elevated BMI (i.e. severe and morbid obesity) are often used as contraindications for transplantation $[57,58]$. The variable $E C D_{i j t}$ indicates the number of expanded criteria donor (ECD) transplants that center $j$ conducted in the 1-year period leading up to time period $t$. An ECD is distinct from a standard criteria donor transplant because ECD organs are obtained from deceased donors who are over the age of 50 with at least two comorbidities including high blood pressure, a creatinine-a blood test indicating impaired kidney function - of at least 1.5 , or stroke-related death. ECD organs have a higher rate of delayed graft function, higher probability of acute rejection, and shorter longevity [59]. However, ECD transplants, which reduce the excess demand for organs, increase a center's transplant volume and reduce patients' waiting time. The variables

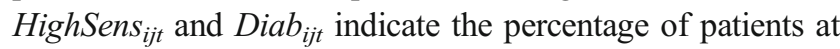
the transplant center that are either highly sensitized or have diabetes. A highly-sensitized patient (a patient with a highly sensitized immune system) is defined to have a panel reactive antibody (PRA) level greater than 80 , on a 0 to 100 scale, increasing the probability that the patient will experience organ rejection if transplanted. Patients with a PRA over 80 have antibodies to approximately $80 \%$ (or more) of the population, making them very difficult to match and are riskier than other patients [60]. Diabetes is also important in estimating a patient's utility because it represents an important risk factor for kidney failure and ESRD. The variable Donations Dijt $_{\text {measures }}$ annual kidney donations in the transplant center's local market which would impact the supply and possibly the demand for kidney transplantation in a given market.

Our before-and-after specification is captured within the $W_{j t}$ and $V_{j t}$ matrices, depending on whether or not we are estimating the sorting equilibrium or the conditional logit models. Depending on the empirical specification, we include the following variables within these matrices: Either $_{j t}$, Graft $_{j}$, Patient $_{j t}$, Post $t_{j}$, PostEither ${ }_{j t}$, PostGraft ${ }_{j t}$ and PostPatient $t_{j t}$. The variables Graft $t_{j t}$ and Patient $t_{j t}$ are dummy variables that 
indicate whether or not transplant center $j$ did not meet the CMS CoPs in period $t$ for graft survival and patient survival outcomes, respectively. The variable Either $_{j t}$ is an indicator for whether or not they did not meet the CMS CoPs for either graft or patient survival outcomes. The two quality measures are often times correlated. When a center does not meet the 1year patient survival criteria they also may not meet the 1-year graft survival metrics because patient deaths are included as graft failures. In any given period $t$, a center that fails to meet the CoPs on graft survival outcomes but meets the standards for patient survival outcomes will have a value of one for Graft $_{j t}$, zero for Patient $t_{j}$, and one for Either ${ }_{j t}$. The variable Post $_{j t}$ is a dummy variable that indicates whether or not the period considered is post-CoP and the variables PostEither ${ }_{j t}$, PostGraft $_{j t}$ and PostPatient ${ }_{j t}$ are dummy variable interactions between Post $_{j t}$ and the dummy variables Either ${ }_{j t}$, Graft $_{j t}$, and Patient $_{j t}$. The coefficients on these three interaction variables are the primary focus of this study and capture the effects that the regulation on patient selection.

In the sorting equilibrium model, we again utilize the data contained in $Z_{i j t}$ to explain variation in $\delta_{j t}$ that is not a result of the report cards or the regulation. This is achieved by averaging all of the variables in $Z_{i j t}$ across all $i$ individuals to construct our $W_{j t}$ matrix. In addition to these initial specifications, we estimate another set of models that interact the treatment (Either $_{j t}$, Graft ${ }_{j t}$, Patient $_{j t}$, Post $_{j t}$, PostEither ${ }_{j t}$, PostGraft $_{j t}$, and PostPatient $\left._{j t}\right)$ and control $\left(E C D_{i j t}\right.$, HighSens Hijt $_{\text {, and Diab }}$, Hit $)$ variables to assess if the report cards and the regulation have a differential impact based on the level of risk a transplant center faces. We select these covariates because they are included in the risk-adjustment models used by the SRTR to calculate the expected 1-year graft and patient survival rates. We estimated marginal effects, utilizing a simulation method similar to Krinsky and Robb [61, 62], used for elasticity calculations. We take 1000 draws from the parameter distribution and estimate the change in probability resulting from a $1 \%$ change in the covariates for continuous variables and a shift from 0 to 1 for binary variables in the regression. Our results allow to construct $95 \%$ confidence intervals that we use to estimate statistical significance. All regression analyses are performed with Matlab R2019a.

\section{Data description}

We use data on ESRD patients on the United States (U.S.) deceased donor waiting list for kidney transplantation between 2003 and 2010. The primary data source is the United Network for Organ Sharing Standard Transplant Analysis and Research (UNOS STAR) database. The UNOS STAR data provides information on transplant candidates including demographics, medical conditions, dates of listing and transplantation - if any-reported on the registration forms at the transplant center. The analysis is restricted to ESRD patients aged at least 18 years and their transplant center choices.

SRTR reports for 228 transplant centers are linked to the UNOS STAR data to create binary indicator variables for whether a transplant center meets the three non-compliance thresholds defined by the CoPs for either 1-year total graft or patient survival outcomes: a "negative" report card. A total of sixteen sets of report cards are used in this study. We also account for the fact that transplant programs can be active or inactive at different points in time. The activity-inactivity schedule implies that patients have different choice sets over time as each patient's effective choice set only includes those centers that are actively conducting kidney transplants at the time the patient is considering healthcare providers. The analytic sample includes registration information for 245,090 individuals between 2003 and 2010.

The UNOS STAR data provide information on transplant centers selected at listing and on transplant candidates' ZIP codes of residence both at listing and at transplantation. We collect the exact address of the centers using information available on their official websites and from the Health Resources and Services Administration website [63]. We further use the 2012 U.S. Census Bureau TIGER Shapefiles [64] to compute distances to the transplant centers using the centroid of the patients' ZIP codes. These calculations are done using ArcGIS, ArcMap 10.

We further restricted the sample to include only transplant centers within either the ninetieth percentile of distances traveled to transplant centers (158-mile buffer) or the ninety-fifth percentile of distances traveled (232-mile buffer). Additionally, we keep the first listing for each patient and drop multiple listings, which represent less than $10 \%$ of all listings [65]. These steps result in 196,318 and 206,477 patient-year observations for each respective choice set. Altering the spatial buffer substantially modifies the number of potential transplant centers that a patient may be considering. In the ninetiethpercentile choice set model, the average number of available centers is 12.5 , whereas it is 19.3 in the ninety-fifth percentile model. Failure to accurately account for all possible spatial substitutes may generate erroneous parameter estimates and bias our empirical inference [66, 67]. Therefore, we have elected to investigate the robustness of our estimates to a regionally concentrated and a more spatially broad choice sets.

Other center-specific attributes include the average age and BMI of patients actively listed on any given date of interest, the proportion of "active" white transplant candidates and "active" black candidates to account for the racial composition of centers' waiting list, the proportion of female patients actively listed, and the number of transplants from ECDs performed in the past 365 days. Active listings are computed using all registrations at a particular transplant center and subtracting all removals from the waiting list up to a particular 
listing date of interest. The number of active listings for patients with medical conditions such as high sensitization and diabetes are also included. These center-specific characteristics were calculated going back to the first registration record for the centers, which could be as early as January 1, 1972. Using the Organ Procurement and Transplantation Network [68] public data, we also included information on annual kidney donations in the transplant centers local markets (donation service areas or organ procurement organizations (OPOs)).

Organ procurement and allocation is handled at the geographical level by OPOs and centers can only be affiliated with one OPO. Appendix Fig. 1 shows the distribution of OPOs and transplant centers across the U.S.. Because of limited conservation time for organs, the allocation hierarchy happens first at the local area, then regional, and national level. In the current allocation process, access to kidney transplantation greatly depends on the "local" supply of organs and the "local" demand (i.e. waiting list).

\subsection{Descriptive statistics}

Descriptive statistics for waiting list patients and centerspecific characteristics between 2003 and 2010 are presented in Table 1. Transplant candidates are $40 \%$ female, $49 \%$ white, have average age of 50 years, and average BMI in the overweight category $\left(B M I=28 \mathrm{~kg} / \mathrm{m}^{2}\right)$. About $44 \%$ of transplant candidates have diabetes, one of the leading causes of ESRD. On average, ESRD patients travel about 35 miles to their preferred transplant center in the 90th percentile of distances traveled choice set and 43 miles in the 95th percentile of distances traveled choice set.

Considering the center as the unit of observation, on a typical day between January 1, 2003 and September 3, 2010, the size of the waiting list is about 715 and 745 registrations at the average facility for the 90th percentile and 95th percentile of distances choice sets, respectively (Table 1). On average, there are about 120 transplants performed over a year for the 90th percentile and 122 transplants for the 95th percentile of distances at the average facility. Nearly $11 \%$ of these transplants are conducted from ECD donors. The distribution of race ethnicities among patients actively listed shows that black patients constitute about $28 \%$ of patient registered but $34 \%$ of those actively listed versus white patients representing $49 \%$ of patients registered but $44 \%$ of those actively listed. These racial disparities in active listings might suggest a relatively greater access to transplantation for white patients relative to black patients. Compared to the general patient population, patients actively listed are slightly younger ( 49 versus 50 years in the general patient population) and have lower BMI ( 27 versus $28 \mathrm{~kg} / \mathrm{m}^{2}$ ). Annual kidney donations in a donation service area average about 197 donors in the 90th percentile of distances choice set and 196 donors in the 95th percentile choice set.
Considering quality performance measures, there are $5 \%$ of patient-registration-years that are associated with centers not in compliance with the CoPs on either graft or patient survival rates during the pre-regulation period (Table 1). In the postregulation period, that proportion slightly decreases to $4 \%$ of patient registration-years. Patient average age and BMI are comparable across the distance-based choice sets. When examining characteristics of centers in our study, between $32 \%$ $(N=73)$ and $33 \%(N=75)$ are identified as low performing (i.e. a negative report card) pre-CoP. In the regulatory-binding period, post-CoP, there are $29 \%(N=66)$ of transplant centers flagged for low-performance. Low-performing centers are therefore relatively smaller in patient volume than centers in compliance with the CoPs.

\section{Empirical results}

\subsection{Conditional logit model}

Regression results from the conditional logit model are contained in Table 2, where we assess the average effect of the CoPs. We partition the results based on the distance buffers employed and performance measures included in the regressions. We do not run a regression investigating simultaneous low-performance on graft survival and patient survival outcomes because the measures are often times collinear.

The results for both the 90th percentile and 95th percentile of distances traveled choice set models are generally consistent across specifications but the marginal effects estimated on covariates are higher in general when there are more center options available. Distance has a strong negative effect on the choice of the center, a $1 \%$ increase in distance traveled, corresponding to increases by 0.35 miles for the 90th percentile and 0.43 miles for the 95 th percentile of distances traveled, reduces the probability that a center be chosen by $1.1 \%$ and $1.2 \%$, respectively (Table 2). Because the distance effect is presumably non-linear, our estimates only reflect a local effect of the $1 \%$ change and should not be linearly interpolated in terms of a change in the standard deviation. The percentage of highly sensitized patients currently listed at a center negatively impacts that center's selection by potential transplant candidates: a decrease in the choice likelihood by $0.01 \%$ up to $0.03 \%$ for a $1 \%$ increase in the proportion. A higher percentage of waiting-list patients that are white, black, female, or diabetic at a particular center and greater availability of kidney donors in a center's donation area increase the likelihood of that center's choice. Age has a negative and statistically significant effect on the likelihood of a center's choice when considering centers within the 90th percentile of distances, and centers with higher average BMI of patients are less attractive choices for prospective transplant candidates across all regression models. In addition, centers that conduct a 
Table 1 Descriptive statistics for patients seeking kidney transplantation (2003-2010)

Patient Characteristics $(N=\mathbf{2 1 5 , 8 0 8}$ registration-years $)$

\begin{tabular}{lll}
\hline Variable & Mean & Std. Dev \\
\hline Proportion of kidney listing only: Remainder jointly listed for kidney and pancreas & 0.95 & 0.22 \\
Age at listing & 50.02 & 13.10 \\
Female & 0.40 & 0.49 \\
BMI at listing & 27.87 & 5.70 \\
White & 0.49 & 0.50 \\
Black & 0.28 & 0.45 \\
Hispanic & 0.15 & 0.36 \\
Asian & 0.06 & 0.23 \\
Other ethnicity & 0.02 & 0.13 \\
Diabetes & 0.45 & 0.50 \\
Highly sensitized & 0.04 & 0.19 \\
Waiting List Characteristics $(\boldsymbol{N}=\mathbf{2 2 8}$ Centers $)$ & & \\
\end{tabular}

\begin{tabular}{|c|c|c|c|c|}
\hline & \multicolumn{2}{|c|}{$\begin{array}{l}\text { 90th percentile (158-mile) distance } \\
\text { buffer }\end{array}$} & \multicolumn{2}{|c|}{$\begin{array}{l}\text { 95th percentile (232-mile) distance } \\
\text { buffer }\end{array}$} \\
\hline & Mean & Std. Dev & Mean & Std. Dev \\
\hline Distance to transplant center (miles) & 35.45 & 37.10 & 43.01 & 49.33 \\
\hline Active listing & 714.83 & 843.77 & 744.99 & 882.09 \\
\hline Transplants in past year & 119.52 & 79.79 & 121.69 & 80.71 \\
\hline Number of ECD transplants in past year & 13.16 & 11.75 & 13.22 & 11.69 \\
\hline Proportion of white patients & 0.44 & 0.20 & 0.44 & 0.20 \\
\hline Proportion of black patients & 0.34 & 0.20 & 0.34 & 0.20 \\
\hline Proportion of female patients & 0.42 & 0.04 & 0.42 & 0.04 \\
\hline Average age of patients on waiting list & 48.62 & 2.26 & 48.61 & 2.26 \\
\hline Average BMI of patients on waiting list & 26.87 & 2.08 & 26.88 & 2.05 \\
\hline Proportion of patients with diabetes & 0.18 & 0.12 & 0.18 & 0.12 \\
\hline Proportion of highly sensitized patients & 0.07 & 0.06 & 0.05 & 0.05 \\
\hline Annual kidney donors in donation area & 197.27 & 104.41 & 196.00 & 103.51 \\
\hline \multicolumn{5}{|c|}{ Proportion of patients listed at centers failing to meet quality standards on: } \\
\hline Either 1-year graft or patient survival rates pre-CMS CoP & 0.05 & 0.21 & 0.05 & 0.21 \\
\hline 1-year graft survival rate pre-CMS CoP & 0.03 & 0.17 & 0.03 & 0.17 \\
\hline 1-year patient survival rate pre-CMS CoP & 0.03 & 0.18 & 0.03 & 0.18 \\
\hline Either 1-year graft or patient survival rates post-CMS CoP & 0.04 & 0.20 & 0.04 & 0.20 \\
\hline 1-year graft survival rate post-CMS CoP & 0.03 & 0.16 & 0.03 & 0.16 \\
\hline 1 -year patient survival rate post-CMS CoP & 0.03 & 0.16 & 0.03 & 0.16 \\
\hline \multicolumn{5}{|l|}{ Proportion of centers failing to meet quality standards on: } \\
\hline Either 1-year graft or patient survival rates pre-CMS CoP & 0.33 & & 0.32 & \\
\hline 1-year graft survival rate pre-CMS CoP & 0.23 & & 0.23 & \\
\hline 1 -year patient survival rate pre-CMS CoP & 0.23 & & 0.23 & \\
\hline Either 1-year graft or patient survival rates post-CMS CoP & 0.29 & & 0.29 & \\
\hline 1-year graft survival rate post-CMS CoP & 0.21 & & 0.21 & \\
\hline 1 -year patient survival rate post-CMS CoP & 0.19 & & 0.19 & \\
\hline Number of centers & 227 & & 228 & \\
\hline Observations (Registration-years) & 196,318 & & 206,477 & \\
\hline
\end{tabular}

Abbreviations- $B M I$ body mass index, ECD expanded criteria donor, $C M S$ Centers for Medicare and Medicaid Services, CoP Conditions of Participation

higher number of ECD transplants are more attractive to ESRD patients choosing between transplant centers. The negative and statistically significant coefficients estimated on NegRepCard illustrate that patients are less likely to register at a center not meeting quality standards enforced by the CoPs. Moreover, after the regulation is implemented, low quality performance on any of the three outcomes has an increasing negative effect on centers' selection. We estimate decreases in the probability of choice ranging from a low of $4.2 \%$ for either graft or patient survival outcomes to a high of $6.9 \%$ for 1-year graft survival outcome in the 90th percentile of distances choice set and from a low of $3.5 \%$ 
Table 2 The effect of regulatory-binding report cards on patient selection of a transplant center: conditional logit model

Panel A: 90th percentile of distances traveled (158-Mile Buffer)

\begin{tabular}{|c|c|c|c|c|c|c|}
\hline \multirow[b]{2}{*}{ Variable } & \multicolumn{2}{|c|}{ Either Graft or Patient Survival Rate } & \multicolumn{2}{|c|}{ Graft Survival Rate } & \multicolumn{2}{|c|}{ Patient Survival Rate } \\
\hline & Coeff. & Marg. Eff. $\dagger$ & Coeff. & Marg. Eff. & Coeff. & Marg.Eff. \\
\hline Distance & $\begin{array}{l}-46.366^{* * * *} \\
(0.138)\end{array}$ & $\begin{array}{l}-1.143^{\phi} \\
(0.003)\end{array}$ & $\begin{array}{l}-46.353 * * * \\
(0.138)\end{array}$ & $\begin{array}{l}-1.142^{\phi} \\
(0.003)\end{array}$ & $\begin{array}{l}-46.383 * * * \\
(0.138)\end{array}$ & $\begin{array}{l}-1.143^{\phi} \\
(0.003)\end{array}$ \\
\hline Average age of patients & $\begin{array}{l}-0.271^{*} \\
(0.140)\end{array}$ & $\begin{array}{l}-0.086^{\phi} \\
(0.042)\end{array}$ & $\begin{array}{l}-0.285^{* *} \\
(0.139)\end{array}$ & $\begin{array}{l}-0.089^{\phi} \\
(0.042)\end{array}$ & $\begin{array}{l}-0.167 \\
(0.140)\end{array}$ & $\begin{array}{l}-0.053 \\
(0.043)\end{array}$ \\
\hline Proportion of white patients & $\begin{array}{l}1.809 * * * \\
(0.038)\end{array}$ & $\begin{array}{l}0.492^{\phi} \\
(0.010)\end{array}$ & $\begin{array}{l}1.819 * * * \\
(0.038)\end{array}$ & $\begin{array}{l}0.495^{\phi} \\
(0.011)\end{array}$ & $\begin{array}{l}1.834 * * * \\
(0.038)\end{array}$ & $\begin{array}{l}0.499^{\phi} \\
(0.009)\end{array}$ \\
\hline Proportion of black patients & $\begin{array}{l}0.803^{* * * *} \\
(0.040)\end{array}$ & $\begin{array}{l}0.174^{\phi} \\
(0.009)\end{array}$ & $\begin{array}{l}0.798^{* * * *} \\
(0.040)\end{array}$ & $\begin{array}{l}0.174^{\phi} \\
(0.009)\end{array}$ & $\begin{array}{l}0.820^{* * * *} \\
(0.040)\end{array}$ & $\begin{array}{l}0.178^{\phi} \\
(0.008)\end{array}$ \\
\hline Proportion of female patients & $\begin{array}{l}0.562 * * * \\
(0.044)\end{array}$ & $\begin{array}{l}0.151^{\Phi} \\
(0.012)\end{array}$ & $\begin{array}{l}0.563 * * * \\
(0.044)\end{array}$ & $\begin{array}{l}0.152^{\phi} \\
(0.011)\end{array}$ & $\begin{array}{l}0.542^{* * * *} \\
(0.044)\end{array}$ & $\begin{array}{l}0.146^{\Phi} \\
(0.012)\end{array}$ \\
\hline Average BMI of patients & $\begin{array}{l}-1.412 * * * \\
(0.135)\end{array}$ & $\begin{array}{l}-0.241^{\phi} \\
(0.021)\end{array}$ & $\begin{array}{l}-1.401 * * * \\
(0.135)\end{array}$ & $\begin{array}{l}-0.240^{\phi} \\
(0.021)\end{array}$ & $\begin{array}{l}-1.476^{* * * *} \\
(0.134)\end{array}$ & $\begin{array}{l}-0.253^{\phi} \\
(0.021)\end{array}$ \\
\hline ECD transplants in past year & $\begin{array}{l}3.862 * * * \\
(0.024)\end{array}$ & $\begin{array}{l}0.321^{\phi} \\
(0.002)\end{array}$ & $\begin{array}{l}3.845 * * * \\
(0.024)\end{array}$ & $\begin{array}{l}0.320^{\Phi} \\
(0.002)\end{array}$ & $\begin{array}{l}3.880 * * * \\
(0.024)\end{array}$ & $\begin{array}{l}0.323^{\phi} \\
(0.002)\end{array}$ \\
\hline Proportion of highly sensitized patients & $\begin{array}{l}-0.409 * * * \\
(0.083)\end{array}$ & $\begin{array}{l}-0.012^{\phi} \\
(0.002)\end{array}$ & $\begin{array}{l}-0.406^{* * * *} \\
(0.083)\end{array}$ & $\begin{array}{l}-0.012^{\phi} \\
(0.003)\end{array}$ & $\begin{array}{l}-0.387 * * * \\
(0.082)\end{array}$ & $\begin{array}{l}-0.012^{\phi} \\
(0.003)\end{array}$ \\
\hline Proportion of patients with diabetes & $\begin{array}{l}0.288^{* * * *} \\
(0.047)\end{array}$ & $\begin{array}{l}0.032^{\Phi} \\
(0.005)\end{array}$ & $\begin{array}{l}0.273 * * * \\
(0.047)\end{array}$ & $\begin{array}{l}0.030^{\phi} \\
(0.005)\end{array}$ & $\begin{array}{l}0.262 * * * \\
(0.047)\end{array}$ & $\begin{array}{l}0.029^{\phi} \\
(0.005)\end{array}$ \\
\hline Annual kidney donors in donation area & $\begin{array}{l}0.068^{* * * *} \\
(0.005)\end{array}$ & $\begin{array}{l}0.094^{\Phi} \\
(0.007)\end{array}$ & $\begin{array}{l}0.067 * * * \\
(0.005)\end{array}$ & $\begin{array}{l}0.092^{\phi} \\
(0.007)\end{array}$ & $\begin{array}{l}0.067 * * * \\
(0.005)\end{array}$ & $\begin{array}{l}0.092^{\phi} \\
(0.007)\end{array}$ \\
\hline Negative report card & $\begin{array}{l}-0.133 * * * \\
(0.014)\end{array}$ & $\begin{array}{l}-8.150^{\phi} \\
(0.779)\end{array}$ & $\begin{array}{l}-0.163^{* * * *} \\
(0.018)\end{array}$ & $\begin{array}{l}-10.053^{\phi} \\
(1.059)\end{array}$ & $\begin{array}{l}-0.059 * * * \\
(0.018)\end{array}$ & $\begin{array}{l}-3.667^{\phi} \\
(1.159)\end{array}$ \\
\hline Negative report card*post CMS CoP & $\begin{array}{l}-0.065 * * * \\
(0.020)\end{array}$ & $\begin{array}{l}-4.159^{\phi} \\
(1.184)\end{array}$ & $\begin{array}{l}-0.110^{* * * *} \\
(0.024)\end{array}$ & $\begin{array}{l}-6.870^{\phi} \\
(1.413)\end{array}$ & $\begin{array}{l}-0.081 * * * \\
(0.024)\end{array}$ & $\begin{array}{l}-5.070^{\phi} \\
(1.577)\end{array}$ \\
\hline $\begin{array}{l}\text { Observations } \\
\text { Log-Likelihood (0) } \\
\text { Log-Likelihood }\end{array}$ & \multicolumn{2}{|c|}{$\begin{array}{c}196,318 \\
-429,556 \\
-279,972\end{array}$} & \multicolumn{2}{|c|}{$\begin{array}{c}196,318 \\
-429,556 \\
-279,938\end{array}$} & \multicolumn{2}{|c|}{$\begin{array}{c}196,318 \\
-429,556 \\
-280,084\end{array}$} \\
\hline
\end{tabular}

Panel B: 95th percentile of distances traveled (232-Mile Buffer)

\begin{tabular}{|c|c|c|c|c|c|c|}
\hline \multirow[b]{2}{*}{ Variable } & \multicolumn{2}{|c|}{ Either Graft or Patient Survival Rate } & \multicolumn{2}{|c|}{ Graft Survival Rate } & \multicolumn{2}{|c|}{ Patient Survival Rate } \\
\hline & Coeff. & Marg. Eff. & Coeff. & Marg. Eff. & Coeff. & Marg.Eff \\
\hline Distance & $\begin{array}{l}-38.689 * * * \\
(0.099)\end{array}$ & $\begin{array}{l}-1.240^{\phi} \\
(0.003)\end{array}$ & $\begin{array}{l}-38.673 \text { *** } \\
(0.099)\end{array}$ & $\begin{array}{l}-1.239^{\phi} \\
(0.003)\end{array}$ & $\begin{array}{l}-38.706 * * * \\
(0.099)\end{array}$ & $\begin{array}{l}-1.241^{\phi} \\
(0.003)\end{array}$ \\
\hline Average age of patients & $\begin{array}{l}0.033 \\
(0.132)\end{array}$ & $\begin{array}{l}0.009 \\
(0.042)\end{array}$ & $\begin{array}{l}0.033 \\
(0.132)\end{array}$ & $\begin{array}{l}0.010 \\
(0.042)\end{array}$ & $\begin{array}{l}0.149 \\
(0.133)\end{array}$ & $\begin{array}{l}0.048 \\
(0.042)\end{array}$ \\
\hline Proportion of white patients & $\begin{array}{l}1.565^{* * * *} \\
(0.035)\end{array}$ & $\begin{array}{l}0.449^{\phi} \\
(0.010)\end{array}$ & $\begin{array}{l}1.577 * * * \\
(0.035)\end{array}$ & $\begin{array}{l}0.453^{\phi} \\
(0.010)\end{array}$ & $\begin{array}{l}1.585 * * * \\
(0.035)\end{array}$ & $\begin{array}{l}0.455^{\phi} \\
(0.009)\end{array}$ \\
\hline Proportion of black patients & $\begin{array}{l}0.644 * * * \\
(0.037)\end{array}$ & $\begin{array}{l}0.146^{\Phi} \\
(0.009)\end{array}$ & $\begin{array}{l}0.641 * * * \\
(0.037)\end{array}$ & $\begin{array}{l}0.146^{\phi} \\
(0.009)\end{array}$ & $\begin{array}{l}0.659 * * * \\
(0.037)\end{array}$ & $\begin{array}{l}0.150^{\phi} \\
(0.008)\end{array}$ \\
\hline Proportion of female patients & $\begin{array}{l}0.654 * * * \\
(0.041)\end{array}$ & $\begin{array}{l}0.185^{\Phi} \\
(0.012)\end{array}$ & $\begin{array}{l}0.653 * * * \\
(0.041)\end{array}$ & $\begin{array}{l}0.185^{\phi} \\
(0.011)\end{array}$ & $\begin{array}{l}0.629 * * * \\
(0.042)\end{array}$ & $\begin{array}{l}0.178^{\Phi} \\
(0.012)\end{array}$ \\
\hline Average BMI of patients & $\begin{array}{l}-1.468 * * * \\
(0.130)\end{array}$ & $\begin{array}{l}-0.263^{\phi} \\
(0.021)\end{array}$ & $\begin{array}{l}-1.464 * * * \\
(0.130)\end{array}$ & $\begin{array}{l}-0.263^{\phi} \\
(0.022)\end{array}$ & $\begin{array}{l}-1.532 * * * \\
(0.130)\end{array}$ & $\begin{array}{l}-0.275^{\phi} \\
(0.021)\end{array}$ \\
\hline ECD transplants in past year & $\begin{array}{l}3.934 * * * \\
(0.022)\end{array}$ & $\begin{array}{l}0.343^{\phi} \\
(0.002)\end{array}$ & $\begin{array}{l}3.915 * * * \\
(0.022)\end{array}$ & $\begin{array}{l}0.341^{\phi} \\
(0.002)\end{array}$ & $\begin{array}{l}3.960 * * * \\
(0.022)\end{array}$ & $\begin{array}{l}0.345^{\phi} \\
(0.002)\end{array}$ \\
\hline Proportion of highly sensitized patients & $\begin{array}{l}-0.888 * * * \\
(0.077)\end{array}$ & $\begin{array}{l}-0.028^{\phi} \\
(0.002)\end{array}$ & $\begin{array}{l}-0.888 * * * \\
(0.077)\end{array}$ & $\begin{array}{l}-0.029^{\phi} \\
(0.003)\end{array}$ & $\begin{array}{l}-0.863 * * * \\
(0.077)\end{array}$ & $\begin{array}{l}-0.028^{\phi} \\
(0.003)\end{array}$ \\
\hline Proportion of patients with diabetes & $\begin{array}{l}0.283 * * * \\
(0.044)\end{array}$ & $\begin{array}{l}0.033^{\phi} \\
(0.005)\end{array}$ & $\begin{array}{l}0.262 * * * \\
(0.044)\end{array}$ & $\begin{array}{l}0.031^{\phi} \\
(0.005)\end{array}$ & $\begin{array}{l}0.259 * * * \\
(0.044)\end{array}$ & $\begin{array}{l}0.030^{\Phi} \\
(0.005)\end{array}$ \\
\hline Annual kidney donors in donation area & $\begin{array}{l}0.064 * * * \\
(0.004)\end{array}$ & $\begin{array}{l}0.091^{\Phi} \\
(0.006)\end{array}$ & $\begin{array}{l}0.063 * * * \\
(0.004)\end{array}$ & $\begin{array}{l}0.089^{\Phi} \\
(0.006)\end{array}$ & $\begin{array}{l}0.063 * * * \\
(0.004)\end{array}$ & $\begin{array}{l}0.089^{\Phi} \\
(0.006)\end{array}$ \\
\hline Negative report card & $\begin{array}{l}-0.165 * * * \\
(0.014)\end{array}$ & $\begin{array}{l}-10.529^{\phi} \\
(0.758)\end{array}$ & $\begin{array}{l}-0.193 * * * \\
(0.017)\end{array}$ & $\begin{array}{l}-12.321^{\phi} \\
(1.031)\end{array}$ & $\begin{array}{l}-0.108 * * * \\
(0.017)\end{array}$ & $\begin{array}{l}-6.964^{\phi} \\
(1.113)\end{array}$ \\
\hline Negative report card*post CMS CoP & $\begin{array}{l}-0.065 * * * \\
(0.019)\end{array}$ & $\begin{array}{l}-4.393^{\phi} \\
(1.190)\end{array}$ & $\begin{array}{l}-0.108 * * * \\
(0.023)\end{array}$ & $\begin{array}{l}-7.091^{\phi} \\
(1.421)\end{array}$ & $\begin{array}{l}-0.053 * * \\
(0.023)\end{array}$ & $\begin{array}{l}-3.530^{\phi} \\
(1.621)\end{array}$ \\
\hline $\begin{array}{l}\text { Observations } \\
\text { Log-Likelihood (0) } \\
\text { Log-Likelihood }\end{array}$ & \multicolumn{2}{|c|}{$\begin{array}{c}206,477 \\
-548,806 \\
-322,742\end{array}$} & \multicolumn{2}{|c|}{$\begin{array}{c}206,477 \\
-548,806 \\
-322,723\end{array}$} & \multicolumn{2}{|c|}{$\begin{array}{c}206,477 \\
-548,806 \\
-322,906\end{array}$} \\
\hline
\end{tabular}

Abbreviations- $B M I$ body mass index, ECD expanded criteria donor, CMS Centers for Medicare and Medicaid Services, CoP Conditions of Participation. Standard errors are reported in parentheses. $†$ Marginal effects are estimated using a simulation method similar to the Krinsky, Robb [61] and Krinsky, Robb [62] method used for elasticity calculations. We take 1000 draws from the parameter distribution and estimate the change in probability resulting from a $1 \%$ change in the covariates for continuous variables and a shift from 0 to 1 for binary variables in the regression. Our results allow to construct $95 \%$ confidence intervals that we use to estimate statistical significance. Inference: $* * * p<0.01, * * p<0.05,{ }^{*} p<0.1 ;{ }^{\phi}$ indicates statistically significant at $>95 \%$ level 
for 1-year patient survival outcome to a high of $7.1 \%$ for 1 year graft survival outcome in the 95th percentile of distances choice set.

\subsection{Sorting equilibrium model}

The results from the sorting equilibrium model are presented in Tables 3 and 4 . Table 3 presents the parameter estimates for $\beta$ and $\gamma$ and Table 4 presents the second-stage decomposition of the center and time-specific constants, $\delta_{j t}$, captured by Eq. 2 . The results from our first stage are similar to those observed in the conditional logit model with some notable exceptions. The positive effects estimated for the percentage of white, black, and female patients at a center in the conditional logit model have flipped to negative and statistically significant effects in both choice sets for the proportion of female and in the more restrictive choice set for the proportion of white patients (Table 3). The coefficients on average age, BMI and proportion of highly sensitized patients also change to statistically significant and positive effects in the first-stage sorting equilibrium model relative to the conditional logit. These differences, are driven by the center-time-level fixed effects, $\delta_{j t}$, which control for center-specific heterogeneity.

The decomposition of the center-level fixed effects in Table 4 indicates that centers with a higher proportion of female patients-only statistically significant in the 90th percentile choice set model-larger proportions of white and black patients, as well as a higher number of ECD transplants have a higher $\delta_{j t}$. Factors that reduce the fixed effect, $\delta_{j t}$, level include having relatively older patients, patients with a higher BMI on average, a higher percentage of highly sensitized or diabetic patients, and a higher number of kidney donors in the donation area. A negative report card has no impact on patient sorting across transplant centers post-CoP, in both choice set models (Table 4). Nonetheless, the time effect measured with the post-CoP variable has a negative and significant effects on $\delta_{j t}$ across all quality measures. Lastly, we observe a strong degree of congestion $(\rho)$ in the 90th percentile choice set model indicating that an increase in the number of patients selecting a center in a given time period reduces the probability that another patient will select that center. Though we also estimate congestion in the more flexible model, the parameters are not statistically different from zero.

\subsection{Test for heterogeneous treatment effects across centers' perceived level of risk}

After allowing for the impact of the regulation to vary with the center's perceived level of risk, in the post-CoP period, we find that a higher number of ECD transplants and a higher proportion of highly sensitized and diabetic patients increase the probability of a center being chosen when quality standards are not met in the models considering performance on either survival measure or on just the patient survival outcomes in both choice models (Table 5). While, the estimated effects for a higher proportion of patients with diabetes remain positive on the likelihood of a center's choice when the center has a negative report card for the 1-year graft survival measure, the effects of ECD transplants and proportion of highly sensitized patients become negative and statistically significant for that performance measure.

In sum, the parameter estimates from the conditional logit model do not provide a clear pattern of behavioral response when we allow the effect of low-performance designation in the post-regulation period to vary with patient risk covariates (Table 5). The results from the sorting equilibrium model generate a slightly more consistent behavioral response (Tables 6 and 7). Focusing on the firststage sorting equilibrium results in Table 6 , in the postCMS period, the proportion of highly sensitized patients has positive effects by increasing the likelihood of center choice, while the number of ECD transplants and the proportion of diabetic patients have negative effects on center choice in presence of negative report cards in both choice set specifications (Table 6). We estimate strong congestion effects in the more restrictive (90th percentile) choice model: the coefficients on the share $(\rho)$ variable are negative and statistically significant (Table 7). Therefore, at this spatial resolution of choice, another patient's selection of a center has a negative impact on one's own center selection. Congestion would likely be accentuated by multiple listings which are not included in our analyses. In such a case, our estimates constitute lower bound estimates. The congestion effects completely dissipate in the more flexible model as the estimated coefficients on the share variable become positive, higher in magnitude and statistically significant.

In order to test sensitivity of our results to the choice set assumption made, we estimate results using the 75 th percentile of distances traveled (Appendix Tables 8, 9, 10, 11) with an average of 6.4 centers available to each patient that corresponds approximately to a 74-mile buffer. The results (Appendix Table 11) are consistent with those observed from the 90th percentile of distances traveled. Interestingly, the rapid increase in the number of center alternatives in the choice set (from 12.5 to 19.3 in the 90th percentile and 95 th percentile of distances choice sets, respectively) reduces the stronger congestion effects estimated in the more restrictive choice models. 
Table 3 The effect of regulatory-binding report cards on patient selection of a transplant center: first stage of the sorting equilibrium model

\begin{tabular}{|c|c|c|c|c|}
\hline \multirow[b]{2}{*}{ Variable } & \multicolumn{2}{|c|}{$\begin{array}{l}\text { 90th Percentile of Distance Traveled (158-Mile } \\
\text { Buffer) }\end{array}$} & \multicolumn{2}{|c|}{$\begin{array}{l}\text { 95th Percentile of Distance Traveled (232-Mile } \\
\text { Buffer) }\end{array}$} \\
\hline & Coeff. & Marg. Eff. $\dagger$ & Coeff. & Marg. Eff. \\
\hline Distance & $\begin{array}{l}-56.931 * * * \\
(0.149)\end{array}$ & $\begin{array}{l}-1.222^{\phi} \\
(0.003)\end{array}$ & $\begin{array}{l}-47.845^{* * *} \\
(0.107)\end{array}$ & $\begin{array}{l}-1.329^{\phi} \\
(0.003)\end{array}$ \\
\hline Average age of patients & $\begin{array}{l}7.243 * * * \\
(0.186)\end{array}$ & $\begin{array}{l}2.034^{\phi} \\
(0.052)\end{array}$ & $\begin{array}{l}7.526 * * * \\
(0.176)\end{array}$ & $\begin{array}{l}2.391^{\phi} \\
(0.051)\end{array}$ \\
\hline Proportion of white patients & $\begin{array}{l}-5.037 * * * \\
(0.043)\end{array}$ & $\begin{array}{l}-1.207^{\phi} \\
(0.011)\end{array}$ & $\begin{array}{l}-3.089 * * * \\
(0.039)\end{array}$ & $\begin{array}{l}-0.795^{\phi} \\
(0.011)\end{array}$ \\
\hline Proportion of black patients & $\begin{array}{l}-3.107 * * * \\
(0.047)\end{array}$ & $\begin{array}{l}-0.605^{\phi} \\
(0.010)\end{array}$ & $\begin{array}{l}-1.745 * * * \\
(0.043)\end{array}$ & $\begin{array}{l}-0.364^{\phi} \\
(0.010)\end{array}$ \\
\hline Proportion of female patients & $\begin{array}{l}-2.373 * * * \\
(0.076)\end{array}$ & $\begin{array}{l}-0.570^{\phi} \\
(0.018)\end{array}$ & $\begin{array}{l}-2.497 * * * \\
(0.070)\end{array}$ & $\begin{array}{l}-0.622^{\phi} \\
(0.017)\end{array}$ \\
\hline Average BMI of patients & $\begin{array}{l}12.829 * * * \\
(0.155)\end{array}$ & $\begin{array}{l}1.982^{\phi} \\
(0.023)\end{array}$ & $\begin{array}{l}7.815^{* * * *} \\
(0.150)\end{array}$ & $\begin{array}{l}1.122^{\phi} \\
(0.023)\end{array}$ \\
\hline ECD transplants in past year & $\begin{array}{l}0.289 * * * \\
(0.028)\end{array}$ & $\begin{array}{l}0.022^{\phi} \\
(0.002)\end{array}$ & $\begin{array}{l}0.362 * * * \\
(0.026)\end{array}$ & $\begin{array}{l}0.031^{\phi} \\
(0.002)\end{array}$ \\
\hline Proportion of highly sensitized patients & $\begin{array}{l}2.133 * * * \\
(0.096)\end{array}$ & $\begin{array}{l}0.057^{\phi} \\
(0.003)\end{array}$ & $\begin{array}{l}2.204 * * * \\
(0.089)\end{array}$ & $\begin{array}{l}0.053^{\phi} \\
(0.003)\end{array}$ \\
\hline Proportion of patients with diabetes & $\begin{array}{l}2.696 * * * \\
(0.051)\end{array}$ & $\begin{array}{l}0.269^{\phi} \\
(0.005)\end{array}$ & $\begin{array}{l}2.722 * * * \\
(0.048)\end{array}$ & $\begin{array}{l}0.268^{\phi} \\
(0.005)\end{array}$ \\
\hline Annual kidney donors in donation area & $\begin{array}{l}0.740 * * * \\
(0.006)\end{array}$ & $\begin{array}{l}0.925^{\phi} \\
(0.007)\end{array}$ & $\begin{array}{l}0.686 \text { *** } \\
(0.005)\end{array}$ & $\begin{array}{l}0.881^{\phi} \\
(0.006)\end{array}$ \\
\hline Observations & & 318 & & 477 \\
\hline Log-Likelihood (0) & & 365 & & 926 \\
\hline Log-Likelihood & & 142 & & 893 \\
\hline
\end{tabular}

Abbreviations- $B M I$ body mass index, $E C D$ expanded criteria donor. Standard errors are reported in parentheses. $\uparrow$ Marginal effects are estimated using a simulation method similar to the Krinsky, Robb [61] and Krinsky, Robb [62] method used for elasticity calculations. We take 1000 draws from the parameter distribution and estimate the change in probability resulting from a $1 \%$ change in the covariates for continuous variables and a shift from 0 to 1 for binary variables in the regression. Our results allow to construct $95 \%$ confidence intervals that we use to estimate statistical significance. Inference: $* * * p<0.01, * * p<0.05, * p<0.1{ }^{\phi}{ }^{\phi}$ indicates statistically significant at $>95 \%$ level

\section{Conclusion}

Healthcare report cards allow patients and referring physicians to make better informed decisions and seek to stimulate increases in healthcare quality, whereas regulatory oversight increases accountability of providers while stimulating improved quality. Using a unique dataset on a decision environment where healthcare quality information is critical-organ transplantation - and where report card information imposes a binding constraint on providers following regulation, we investigate whether additional regulatory oversight by the CMS influences patient sorting via changes in patient volume.
Using a before-and-after estimation strategy, we control for the impact that the report cards have on patient sorting and separate the impact of the binding regulatory constraint. Our conditional logit results provide support for the hypothesis that a binding regulatory constraint increases consumer and possibly provider response to healthcare quality report cards. However, when we control for the endogenous sorting of patients across centers as well as center-level heterogeneity in a sorting equilibrium model, we find that the additional regulatory oversight does not impact patient sorting on average. This not only highlights the importance of controlling for center-level heterogeneity as it is found to significantly influence center choice, but also suggests that adding a regulatory constraint to existing healthcare report 
Table 4 The effect of regulatory-binding report cards on patient selection of a transplant center: second stage of the sorting equilibrium model

\begin{tabular}{|c|c|c|c|c|c|c|}
\hline \multirow[b]{2}{*}{ Variable } & \multicolumn{3}{|c|}{ 90th Percentile of Distances Traveled (158-Mile Buffer) } & \multicolumn{3}{|c|}{ 95th Percentile of Distances Traveled (232-Mile Buffer) } \\
\hline & $\begin{array}{l}\text { Either Graft or Patient } \\
\text { Survival Rate } \\
\text { Coeff. }\end{array}$ & $\begin{array}{l}\text { Graft Survival } \\
\text { Rate } \\
\text { Coeff. }\end{array}$ & $\begin{array}{l}\text { Patient Survival } \\
\text { Rate } \\
\text { Coeff. }\end{array}$ & $\begin{array}{l}\text { Either Graft or } \\
\text { Patient Survival Rate } \\
\text { Coeff. }\end{array}$ & $\begin{array}{l}\text { Graft Survival } \\
\text { Rate } \\
\text { Coeff. }\end{array}$ & $\begin{array}{l}\text { Patient Survival } \\
\text { Rate } \\
\text { Coeff. }\end{array}$ \\
\hline Constant & $\begin{array}{l}9.703 * * * \\
(0.925)\end{array}$ & $\begin{array}{l}9.692 * * * \\
(0.925)\end{array}$ & $\begin{array}{l}9.738 * * * \\
(0.925)\end{array}$ & $\begin{array}{l}9.232 * * * \\
(1.194)\end{array}$ & $\begin{array}{l}9.242 * * * \\
(1.193)\end{array}$ & $\begin{array}{l}9.268 * * * \\
(1.194)\end{array}$ \\
\hline Average age of patients & $\begin{array}{l}-12.407 * * * \\
(1.706)\end{array}$ & $\begin{array}{l}-12.333 * * * \\
(1.706)\end{array}$ & $\begin{array}{l}-12.509 * * * \\
(1.705)\end{array}$ & $\begin{array}{l}-4.737 * \\
(2.195)\end{array}$ & $\begin{array}{l}-4.736^{*} \\
(2.193)\end{array}$ & $\begin{array}{l}-4.765 * \\
(2.193)\end{array}$ \\
\hline Proportion of white patients & $\begin{array}{l}3.070 * * * \\
(0.253)\end{array}$ & $\begin{array}{l}3.062 * * * \\
(0.253)\end{array}$ & $\begin{array}{l}3.070 * * * \\
(0.253)\end{array}$ & $\begin{array}{l}4.290 * * * \\
(0.322)\end{array}$ & $\begin{array}{l}4.294 * * * \\
(0.322)\end{array}$ & $\begin{array}{l}4.281 * * * \\
(0.322)\end{array}$ \\
\hline Proportion of black patients & $\begin{array}{l}0.907 * * * \\
(0.248)\end{array}$ & $\begin{array}{l}0.904 * * * \\
(0.247)\end{array}$ & $\begin{array}{l}0.898 * * * \\
(0.247)\end{array}$ & $\begin{array}{l}1.904 * * * \\
(0.320)\end{array}$ & $\begin{array}{l}1.892 * * * \\
(0.320)\end{array}$ & $\begin{array}{l}1.880 * * * \\
(0.320)\end{array}$ \\
\hline Proportion of female patients & $\begin{array}{l}2.763 * * * \\
(0.650)\end{array}$ & $\begin{array}{l}2.731 * * * \\
(0.650)\end{array}$ & $\begin{array}{l}2.746 * * * \\
(0.649)\end{array}$ & $\begin{array}{l}0.338 \\
(0.829)\end{array}$ & $\begin{array}{l}0.326 \\
(0.829)\end{array}$ & $\begin{array}{l}0.258 \\
(0.829)\end{array}$ \\
\hline Average BMI of patients & $\begin{array}{l}-13.037 * * * \\
(2.322)\end{array}$ & $\begin{array}{l}-13.094 * * * \\
(2.319)\end{array}$ & $\begin{array}{l}-12.894 * * * \\
(2.319)\end{array}$ & $\begin{array}{l}-15.406 * * * \\
(2.984)\end{array}$ & $\begin{array}{l}-15.487 * * * \\
(2.978)\end{array}$ & $\begin{array}{l}-15.296^{* * * *} \\
(2.981)\end{array}$ \\
\hline ECD transplants in past year & $\begin{array}{l}7.230 * * * \\
(0.708)\end{array}$ & $\begin{array}{l}7.248^{* * * *} \\
(0.709)\end{array}$ & $\begin{array}{l}7.283 * * * \\
(0.709)\end{array}$ & $\begin{array}{l}7.630 * * * \\
(0.971)\end{array}$ & $\begin{array}{l}7.591 * * * \\
(0.970)\end{array}$ & $\begin{array}{l}7.711 * * * \\
(0.973)\end{array}$ \\
\hline $\begin{array}{l}\text { Proportion of highly } \\
\text { sensitized patients }\end{array}$ & $\begin{array}{l}-6.250 * * * \\
(0.962)\end{array}$ & $\begin{array}{l}-6.234 * * * \\
(0.962)\end{array}$ & $\begin{array}{l}-6.249 * * * \\
(0.962)\end{array}$ & $\begin{array}{l}-6.144 * * * \\
(1.243)\end{array}$ & $\begin{array}{l}-6.105^{* * * *} \\
(1.242)\end{array}$ & $\begin{array}{l}-6.108 * * * \\
(1.243)\end{array}$ \\
\hline $\begin{array}{l}\text { Proportion of patients } \\
\text { with diabetes }\end{array}$ & $\begin{array}{l}-3.642 * * * \\
(0.545)\end{array}$ & $\begin{array}{l}-3.662 * * * \\
(0.545)\end{array}$ & $\begin{array}{l}-3.619 * * * \\
(0.545)\end{array}$ & $\begin{array}{l}-6.957 * * * \\
(0.708)\end{array}$ & $\begin{array}{l}-6.959 * * * \\
(0.707)\end{array}$ & $\begin{array}{l}-6.937 * * * \\
(0.707)\end{array}$ \\
\hline $\begin{array}{l}\text { Annual kidney donors } \\
\text { in donation area }\end{array}$ & $\begin{array}{l}-0.544^{* * *} \\
(0.045)\end{array}$ & $\begin{array}{l}-0.545^{* * * *} \\
(0.045)\end{array}$ & $\begin{array}{l}-0.547 * * * \\
(0.045)\end{array}$ & $\begin{array}{l}-0.571 * * * \\
(0.058)\end{array}$ & $\begin{array}{l}-0.566^{* * * *} \\
(0.058)\end{array}$ & $\begin{array}{l}-0.581 * * * \\
(0.058)\end{array}$ \\
\hline Negative report card & $\begin{array}{l}0.021 \\
(0.194)\end{array}$ & $\begin{array}{l}0.164 \\
(0.227)\end{array}$ & $\begin{array}{l}-0.132 \\
(0.241)\end{array}$ & $\begin{array}{l}-0.178 \\
(0.251)\end{array}$ & $\begin{array}{l}-0.121 \\
(0.293)\end{array}$ & $\begin{array}{l}-0.288 \\
(0.312)\end{array}$ \\
\hline Post CMS CoP & $\begin{array}{l}-3.172 * * * \\
(0.131)\end{array}$ & $\begin{array}{l}-3.163 * * * \\
(0.129)\end{array}$ & $\begin{array}{l}-3.209 * * * \\
(0.129)\end{array}$ & $\begin{array}{l}-5.023^{* * * *} \\
(0.169)\end{array}$ & $\begin{array}{l}-5.002 * * * \\
(0.167)\end{array}$ & $\begin{array}{l}-5.079 * * * \\
(0.166)\end{array}$ \\
\hline $\begin{array}{l}\text { Negative report card* } \\
\text { post CMS CoP }\end{array}$ & $\begin{array}{l}-0.111 \\
(0.271)\end{array}$ & $\begin{array}{l}-0.244 \\
(0.314)\end{array}$ & $\begin{array}{l}0.255 \\
(0.340)\end{array}$ & $\begin{array}{l}-0.142 \\
(0.350)\end{array}$ & $\begin{array}{l}-0.429 \\
(0.405)\end{array}$ & $\begin{array}{l}0.455 \\
(0.440)\end{array}$ \\
\hline Shares $(\rho) \dagger$ & $\begin{array}{l}-41.580^{* * * *} \\
(13.511)\end{array}$ & $\begin{array}{l}-41.573 * * * \\
(13.527)\end{array}$ & $\begin{array}{l}-42.176^{* * * *} \\
(13.550)\end{array}$ & $\begin{array}{l}-4.699 \\
(14.979)\end{array}$ & $\begin{array}{l}-4.790 \\
(14.999)\end{array}$ & $\begin{array}{l}-4.269 \\
(14.991)\end{array}$ \\
\hline Observations & 3304 & 3304 & 3304 & 3308 & 3308 & 3308 \\
\hline R-squared & 0.488 & 0.488 & 0.488 & 0.554 & 0.555 & 0.554 \\
\hline
\end{tabular}

Abbreviations- $B M I$ body mass index, ECD expanded criteria donor, CMS Centers for Medicare and Medicaid Services, CoP Conditions of Participation. Standard errors are reported in parentheses. $†$ The parameter $\rho$ is the share of patients that have selected a particular transplant center in a particular time period and the corresponding coefficient reported captures the degree of congestion $(-)$ or agglomeration $(+)$. Inference: $* * * p<0.01, * *$ $p<0.05, * p<0.1$

cards may not impact overall patient sorting. The null results estimated could occur if changes in patient volume associated with competing factors negate each other. Our estimates would be justified if patient demand for transplantation continue to increase across all centers over time, regardless of quality performance designation, as the proportion of ESRD incident cases increases [11], but that increase is muted by low-performing centers being increasingly selective of patients they register on their waiting list. It could also be that the regulation influences sorting of specific types of patients which may not be detectable in the general population or that all centers, regardless of quality performance, are becoming increasingly risk averse as suggested by the negative and statistically significant effects estimated for the post-CMS CoP variable. 
Table 5 The effect of regulatory-binding report cards on patient selection of a transplant center: conditional logit model with risk factor interaction terms

Panel A: 90th percentile of distances traveled (158-Mile Buffer)

\begin{tabular}{|c|c|c|c|c|c|c|}
\hline \multirow[b]{2}{*}{ Variable } & \multicolumn{2}{|c|}{$\begin{array}{l}\text { Either Graft or Patient } \\
\text { Survival Rate }\end{array}$} & \multicolumn{2}{|c|}{ Graft Survival Rate } & \multicolumn{2}{|c|}{ Patient Survival Rate } \\
\hline & Coeff. & Marg. Eff. $\dagger$ & Coeff. & Marg. Eff. & Coeff. & Marg. Eff. \\
\hline Distance & $\begin{array}{l}-46.411 * * * \\
(0.138)\end{array}$ & $\begin{array}{l}-1.143^{\phi} \\
(0.003)\end{array}$ & $\begin{array}{l}-46.414 * * * \\
(0.138)\end{array}$ & $\begin{array}{l}-1.142^{\phi} \\
(0.003)\end{array}$ & $\begin{array}{l}-46.432 * * * \\
(0.138)\end{array}$ & $\begin{array}{l}-1.143^{\phi} \\
(0.003)\end{array}$ \\
\hline Average age of patients & $\begin{array}{l}-0.312 * * \\
(0.139)\end{array}$ & $\begin{array}{l}-0.059 \\
(0.042)\end{array}$ & $\begin{array}{l}-0.322 * * \\
(0.139)\end{array}$ & $\begin{array}{l}-0.102^{\phi} \\
(0.040)\end{array}$ & $\begin{array}{l}-0.195 \\
(0.140)\end{array}$ & $\begin{array}{l}-0.061 \\
(0.044)\end{array}$ \\
\hline Proportion of white patients & $\begin{array}{l}1.760 * * * \\
(0.038)\end{array}$ & $\begin{array}{l}0.479^{\phi} \\
(0.011)\end{array}$ & $\begin{array}{l}1.807 * * * \\
(0.038)\end{array}$ & $\begin{array}{l}0.491^{\phi} \\
(0.011)\end{array}$ & $\begin{array}{l}1.764 * * * \\
(0.038)\end{array}$ & $\begin{array}{l}0.479^{\phi} \\
(0.011)\end{array}$ \\
\hline Proportion of black patients & $\begin{array}{l}0.767 * * * \\
(0.041)\end{array}$ & $\begin{array}{l}0.166^{\phi} \\
(0.009)\end{array}$ & $\begin{array}{l}0.793 * * * \\
(0.041)\end{array}$ & $\begin{array}{l}0.172^{\phi} \\
(0.009)\end{array}$ & $\begin{array}{l}0.771 * * * \\
(0.041)\end{array}$ & $\begin{array}{l}0.167^{\phi} \\
(0.009)\end{array}$ \\
\hline Proportion of female patients & $\begin{array}{l}0.528 * * * \\
(0.044)\end{array}$ & $\begin{array}{l}0.139^{\phi} \\
(0.012)\end{array}$ & $\begin{array}{l}0.530 * * * \\
(0.044)\end{array}$ & $\begin{array}{l}0.143^{\phi} \\
(0.011)\end{array}$ & $\begin{array}{l}0.516^{* * *} \\
(0.044)\end{array}$ & $\begin{array}{l}0.139^{\phi} \\
(0.011)\end{array}$ \\
\hline Average BMI of patients & $\begin{array}{l}-1.284 * * * \\
(0.136)\end{array}$ & $\begin{array}{l}-0.231^{\phi} \\
(0.023)\end{array}$ & $\begin{array}{l}-1.251^{* * * *} \\
(0.136)\end{array}$ & $\begin{array}{l}-0.213^{\phi} \\
(0.025)\end{array}$ & $\begin{array}{l}-1.355^{* * * *} \\
(0.135)\end{array}$ & $\begin{array}{l}-0.231^{\phi} \\
(0.024)\end{array}$ \\
\hline ECD transplants in past year & $\begin{array}{l}3.979 * * * \\
(0.035)\end{array}$ & $\begin{array}{l}0.334^{\phi} \\
(0.003)\end{array}$ & $\begin{array}{l}3.880^{* * *} \\
(0.033)\end{array}$ & $\begin{array}{l}0.322^{\phi} \\
(0.003)\end{array}$ & $\begin{array}{l}4.023 * * * \\
(0.035)\end{array}$ & $\begin{array}{l}0.334^{\phi} \\
(0.003)\end{array}$ \\
\hline Proportion of highly sensitized patients & $\begin{array}{l}-2.218 * * * \\
(0.119)\end{array}$ & $\begin{array}{l}-0.064^{\phi} \\
(0.004)\end{array}$ & $\begin{array}{l}-2.174 * * * \\
(0.118)\end{array}$ & $\begin{array}{l}-0.065^{\phi} \\
(0.004)\end{array}$ & $\begin{array}{l}-2.129 * * * \\
(0.118)\end{array}$ & $\begin{array}{l}-0.064^{\phi} \\
(0.003)\end{array}$ \\
\hline Proportion of patients with diabetes & $\begin{array}{l}1.402 * * * \\
(0.072)\end{array}$ & $\begin{array}{l}0.155^{\phi} \\
(0.008)\end{array}$ & $\begin{array}{l}1.302 * * * \\
(0.071)\end{array}$ & $\begin{array}{l}0.145^{\phi} \\
(0.008)\end{array}$ & $\begin{array}{l}1.401 * * * \\
(0.072)\end{array}$ & $\begin{array}{l}0.156^{\phi} \\
(0.008)\end{array}$ \\
\hline Annual kidney donors in donation area & $\begin{array}{l}0.070 * * * \\
(0.005)\end{array}$ & $\begin{array}{l}0.093^{\phi} \\
(0.007)\end{array}$ & $\begin{array}{l}0.073 * * * \\
(0.005)\end{array}$ & $\begin{array}{l}0.100^{\phi} \\
(0.007)\end{array}$ & $\begin{array}{l}0.068 * * * \\
(0.005)\end{array}$ & $\begin{array}{l}0.093^{\phi} \\
(0.007)\end{array}$ \\
\hline Negative report card & $\begin{array}{l}-0.143 * * * \\
(0.034)\end{array}$ & $\begin{array}{l}0.964 \\
(2.133)\end{array}$ & $\begin{array}{l}-0.300^{* * * *} \\
(0.042)\end{array}$ & $\begin{array}{l}-17.733^{\phi} \\
(2.227)\end{array}$ & $\begin{array}{l}0.015 \\
(0.047)\end{array}$ & $\begin{array}{l}1.171 \\
(3.043)\end{array}$ \\
\hline Negative report card $*$ post $\mathrm{CMS}$ CoP & $\begin{array}{l}-0.293 * * * \\
(0.061)\end{array}$ & $\begin{array}{l}-22.750^{\phi} \\
(2.908)\end{array}$ & $\begin{array}{l}-0.051 \\
(0.075)\end{array}$ & $\begin{array}{l}2.900 \\
(4.822)\end{array}$ & $\begin{array}{l}-0.406^{* * *} \\
(0.078)\end{array}$ & $\begin{array}{l}-22.773^{\phi} \\
(3.757)\end{array}$ \\
\hline Post $\mathrm{CMS} \mathrm{CoP} * \mathrm{ECD}$ transplants in past year & $\begin{array}{l}-0.164 * * * \\
(0.049)\end{array}$ & $\begin{array}{l}-0.013^{\phi} \\
(0.004)\end{array}$ & $\begin{array}{l}-0.031 \\
(0.047)\end{array}$ & $\begin{array}{l}-0.003 \\
(0.004)\end{array}$ & $\begin{array}{l}-0.151^{* *} \\
(0.048)\end{array}$ & $\begin{array}{l}-0.013^{\phi} \\
(0.004)\end{array}$ \\
\hline $\begin{array}{l}\text { Post CMS CoP } * \text { proportion of } \\
\text { highly sensitized patients }\end{array}$ & $\begin{array}{l}3.326 * * * \\
(0.165)\end{array}$ & $\begin{array}{l}0.101^{\phi} \\
(0.005)\end{array}$ & $\begin{array}{l}3.533 * * * \\
(0.163)\end{array}$ & $\begin{array}{l}0.111^{\phi} \\
(0.005)\end{array}$ & $\begin{array}{l}3.228 * * * \\
(0.163)\end{array}$ & $\begin{array}{l}0.102^{\phi} \\
(0.005)\end{array}$ \\
\hline $\begin{array}{l}\text { Post CMS CoP } * \text { proportion } \\
\text { of patients with diabetes }\end{array}$ & $\begin{array}{l}-1.703 * * * \\
(0.090)\end{array}$ & $\begin{array}{l}-0.268^{\phi} \\
(0.014)\end{array}$ & $\begin{array}{l}-1.633 * * * \\
(0.089)\end{array}$ & $\begin{array}{l}-0.263^{\phi} \\
(0.015)\end{array}$ & $\begin{array}{l}-1.673 * * * \\
(0.089)\end{array}$ & $\begin{array}{l}-0.269^{\phi} \\
(0.014)\end{array}$ \\
\hline $\begin{array}{l}\text { Negative report card * ECD } \\
\text { transplants in past year }\end{array}$ & $\begin{array}{l}-0.114 \\
(0.116)\end{array}$ & $\begin{array}{l}-0.005^{\phi} \\
(0.001)\end{array}$ & $\begin{array}{l}1.761 * * * \\
(0.234)\end{array}$ & $\begin{array}{l}0.006^{\phi} \\
(0.001)\end{array}$ & $\begin{array}{l}-0.715^{* * *} \\
(0.139)\end{array}$ & $\begin{array}{l}-0.004^{\phi} \\
(0.001)\end{array}$ \\
\hline $\begin{array}{l}\text { Negative report card * proportion of highly } \\
\text { sensitized patients }\end{array}$ & $\begin{array}{l}2.276^{* * * *} \\
(0.438)\end{array}$ & $\begin{array}{l}0.007^{\phi} \\
(0.001)\end{array}$ & $\begin{array}{l}3.379 * * * \\
(0.562)\end{array}$ & $\begin{array}{l}0.006^{\phi} \\
(0.001)\end{array}$ & $\begin{array}{l}2.495 * * * \\
(0.558)\end{array}$ & $\begin{array}{l}0.005^{\phi} \\
(0.001)\end{array}$ \\
\hline $\begin{array}{l}\text { Negative report card * proportion of patients } \\
\text { with diabetes }\end{array}$ & $\begin{array}{l}-1.006^{* * *} \\
(0.179)\end{array}$ & $\begin{array}{l}-0.011^{\phi} \\
(0.002)\end{array}$ & $\begin{array}{l}-1.489^{* * *} \\
(0.213)\end{array}$ & $\begin{array}{l}-0.011^{\phi} \\
(0.002)\end{array}$ & $\begin{array}{l}-1.073^{* * *} \\
(0.235)\end{array}$ & $\begin{array}{l}-0.007^{\phi} \\
(0.002)\end{array}$ \\
\hline $\begin{array}{l}\text { Post CMS CoP * negative report card } * \mathrm{ECD} \\
\text { transplants in past year }\end{array}$ & $\begin{array}{l}0.615 * * * \\
(0.184)\end{array}$ & $\begin{array}{l}0.006^{\phi} \\
(0.001)\end{array}$ & $\begin{array}{l}-1.657 * * * \\
(0.289)\end{array}$ & $\begin{array}{l}-0.007^{\phi} \\
(0.001)\end{array}$ & $\begin{array}{l}0.911 * * * \\
(0.228)\end{array}$ & $\begin{array}{l}0.004^{\phi} \\
(0.001)\end{array}$ \\
\hline $\begin{array}{l}\text { Post CMS CoP } * \text { negative report card } * \\
\text { proportion of highly sensitized patients }\end{array}$ & $\begin{array}{l}0.207 \\
(0.549)\end{array}$ & $\begin{array}{l}0.006^{\phi} \\
(0.002)\end{array}$ & $\begin{array}{l}-4.187 * * * \\
(0.736)\end{array}$ & $\begin{array}{l}-0.010^{\phi} \\
(0.002)\end{array}$ & $\begin{array}{l}1.836^{* *} \\
(0.685)\end{array}$ & $\begin{array}{l}0.004^{\phi} \\
(0.002)\end{array}$ \\
\hline $\begin{array}{l}\text { Post CMS CoP } * \text { negative report card } * \\
\text { proportion of patients with diabetes }\end{array}$ & $\begin{array}{l}1.194 * * * \\
(0.241)\end{array}$ & $\begin{array}{l}0.015^{\phi} \\
(0.004)\end{array}$ & $\begin{array}{l}1.882 * * * \\
(0.284)\end{array}$ & $\begin{array}{l}0.020^{\phi} \\
(0.003)\end{array}$ & $\begin{array}{l}0.972 * * * \\
(0.304)\end{array}$ & $\begin{array}{l}0.009^{\phi} \\
(0.003)\end{array}$ \\
\hline $\begin{array}{l}\text { Observations } \\
\text { Log-Likelihood (0) } \\
\text { Log-Likelihood }\end{array}$ & $\begin{array}{r}196 \\
-42 \\
-27\end{array}$ & $\begin{array}{l}5,318 \\
9,655 \\
9,514\end{array}$ & $\begin{array}{r}196 \\
-42 \\
-27\end{array}$ & $\begin{array}{l}, 318 \\
9,655 \\
9,494\end{array}$ & $\begin{array}{r}196 \\
-42 \\
-27\end{array}$ & $\begin{array}{l}5,318 \\
9,655 \\
9,582\end{array}$ \\
\hline
\end{tabular}

Panel B: 95th Percentile of Distances Traveled (232-Mile Buffer)

\begin{tabular}{|c|c|c|c|c|c|c|}
\hline \multirow[b]{2}{*}{ Variable } & \multicolumn{2}{|c|}{$\begin{array}{l}\text { Either Graft or Patient } \\
\text { Survival Rate }\end{array}$} & \multicolumn{2}{|c|}{ Graft Survival Rate } & \multicolumn{2}{|c|}{ Patient Survival Rate } \\
\hline & Coeff. & Marg. Eff. & Coeff. & Marg. Eff. & Coeff. & Marg. Eff. \\
\hline Distance & $\begin{array}{l}-38.657 * * * \\
(0.099)\end{array}$ & $\begin{array}{l}-1.240^{\phi} \\
(0.003)\end{array}$ & $\begin{array}{l}-38.656^{* * * *} \\
(0.099)\end{array}$ & $\begin{array}{l}-1.240^{\phi} \\
(0.003)\end{array}$ & $\begin{array}{l}-38.672 * * * \\
(0.099)\end{array}$ & $\begin{array}{l}-1.240^{\phi} \\
(0.003)\end{array}$ \\
\hline Average age of patients & $\begin{array}{l}0.057 \\
(0.133)\end{array}$ & $\begin{array}{l}0.061 \\
(0.042)\end{array}$ & $\begin{array}{l}0.041 \\
(0.133)\end{array}$ & $\begin{array}{l}0.012 \\
(0.041)\end{array}$ & $\begin{array}{l}0.182 \\
(0.133)\end{array}$ & $\begin{array}{l}0.059 \\
(0.044)\end{array}$ \\
\hline
\end{tabular}


Table 5 (continued)

Proportion of white patients

Proportion of black patients

Proportion of female patients

Average BMI of patients

ECD transplants in past year

Proportion of highly sensitized patients

Proportion of patients with diabetes

Annual kidney donors in donation area

Negative report card

Negative report card $*$ post CMS CoP

Post CMS CoP $*$ ECD transplants in past year

Post CMS CoP * proportion of highly sensitized patients

Post CMS CoP $*$ proportion of patients with diabetes

Negative report card $*$ ECD transplants in past year

Negative report card * proportion of highly sensitized patients

Negative report card $*$ proportion of patients with diabetes

Post $\mathrm{CMS} \mathrm{CoP} *$ negative report card $*$ ECD transplants in past year

Post CMS CoP * negative report card * proportion of highly

sensitized patients

Post CMS CoP * negative report card * proportion of patients with diabetes

Observations

Log-Likelihood (0)

Log-Likelihood

\begin{tabular}{|c|c|c|c|c|c|}
\hline $1.531 * * *$ & $0.439^{\phi}$ & $1.575 * * *$ & $0.451^{\phi}$ & $1.534 * * *$ & $0.439^{\phi}$ \\
\hline$(0.035)$ & $(0.010)$ & $(0.035)$ & $(0.010)$ & $(0.035)$ & $(0.010)$ \\
\hline $0.621 * * *$ & $0.142^{\phi}$ & $0.641 * * *$ & $0.146^{\phi}$ & $0.628 * * *$ & $0.142^{\phi}$ \\
\hline$(0.037)$ & $(0.008)$ & $(0.037)$ & (0.009) & $(0.037)$ & (0.009) \\
\hline $0.650 * * *$ & $0.179^{\phi}$ & 0.646 *** & $0.183^{\phi}$ & 0.630 *** & $0.178^{\phi}$ \\
\hline$(0.041)$ & $(0.012)$ & $(0.041)$ & $(0.011)$ & $(0.041)$ & $(0.011)$ \\
\hline$-1.390 * * *$ & $-0.260^{\phi}$ & $-1.360 * * *$ & $-0.243^{\phi}$ & $-1.449 * * *$ & $-0.259^{\phi}$ \\
\hline$(0.131)$ & $(0.023)$ & $(0.131)$ & $(0.025)$ & $(0.131)$ & $(0.024)$ \\
\hline $4.041 * * *$ & $0.355^{\phi}$ & $3.957 * * *$ & $0.345^{\phi}$ & $4.086^{* * *}$ & $0.356^{\phi}$ \\
\hline$(0.033)$ & $(0.003)$ & $(0.032)$ & $(0.003)$ & $(0.033)$ & $(0.003)$ \\
\hline$-2.589 * * *$ & $-0.081^{\phi}$ & $-2.551 * * *$ & $-0.082^{\phi}$ & $-2.523 * * *$ & $-0.081^{\phi}$ \\
\hline$(0.112)$ & (0.004) & $(0.112)$ & $(0.004)$ & $(0.112)$ & $(0.003)$ \\
\hline $1.092 * * *$ & $0.127^{\phi}$ & $1.007 * * *$ & $0.118^{\phi}$ & $1.090 * * *$ & $0.128^{\phi}$ \\
\hline$(0.068)$ & $(0.008)$ & $(0.067)$ & $(0.008)$ & $(0.068)$ & $(0.008)$ \\
\hline $0.064 * * *$ & $0.089^{\phi}$ & $0.066^{* * *}$ & $0.094^{\phi}$ & $0.063 * * *$ & $0.089^{\phi}$ \\
\hline (0.004) & $(0.006)$ & $(0.004)$ & $(0.006)$ & $(0.004)$ & $(0.006)$ \\
\hline$-0.172 * * *$ & $-5.796^{\phi}$ & $-0.263 * * *$ & $-16.436^{\phi}$ & $-0.089 * *$ & $-5.611^{\phi}$ \\
\hline$(0.032)$ & (1.989) & $(0.040)$ & $(2.224)$ & $(0.044)$ & $(2.801)$ \\
\hline$-0.342 * * *$ & $-26.425^{\phi}$ & -0.040 & -2.322 & $-0.448 * * *$ & $-26.464^{\phi}$ \\
\hline (0.059) & (2.929) & $(0.072)$ & (4.863) & $(0.075)$ & (3.773) \\
\hline$-0.193 * * *$ & $-0.016^{\phi}$ & -0.060 & -0.006 & $-0.173 * * *$ & $-0.016^{\phi}$ \\
\hline$(0.046)$ & (0.004) & $(0.045)$ & $(0.004)$ & $(0.046)$ & $(0.004)$ \\
\hline $3.022 * * *$ & $0.099^{\phi}$ & $3.261 * * *$ & $0.110^{\phi}$ & $2.943 * * *$ & $0.099^{\phi}$ \\
\hline$(0.153)$ & $(0.005)$ & $(0.151)$ & $(0.005)$ & $(0.152)$ & $(0.005)$ \\
\hline$-1.236^{* * *}$ & $-0.207^{\phi}$ & $-1.155^{* * *}$ & $-0.196^{\phi}$ & $-1.226^{* * *}$ & $-0.208^{\phi}$ \\
\hline$(0.085)$ & $(0.014)$ & $(0.084)$ & $(0.015)$ & $(0.084)$ & $(0.014)$ \\
\hline 0.034 & $0.003^{\phi}$ & $1.503 * * *$ & $0.005^{\phi}$ & $-0.385 * * *$ & $-0.002^{\phi}$ \\
\hline$(0.111)$ & $(0.001)$ & $(0.220)$ & $(0.001)$ & $(0.132)$ & $(0.001)$ \\
\hline $1.532 * * *$ & $0.007^{\phi}$ & $1.850 * * *$ & $0.004^{\phi}$ & $2.284 * * *$ & $0.005^{\phi}$ \\
\hline$(0.398)$ & $(0.001)$ & $(0.507)$ & $(0.001)$ & $(0.500)$ & $(0.001)$ \\
\hline$-0.879 * * *$ & $-0.010^{\phi}$ & $-1.330 * * *$ & $-0.010^{\phi}$ & $-0.938 * * *$ & $-0.006^{\phi}$ \\
\hline$(0.168)$ & (0.002) & (0.199) & $(0.002)$ & $(0.218)$ & $(0.001)$ \\
\hline $0.699 * * *$ & $0.005^{\phi}$ & $-1.265 * * *$ & $-0.005^{\phi}$ & $0.790 * * *$ & $0.003^{\phi}$ \\
\hline$(0.177)$ & $(0.001)$ & $(0.274)$ & $(0.001)$ & $(0.218)$ & $(0.001)$ \\
\hline $1.386 * * *$ & $0.010^{\phi}$ & $-2.648 * * *$ & $-0.006^{\phi}$ & $2.748 * * *$ & $0.007^{\phi}$ \\
\hline$(0.507)$ & $(0.002)$ & $(0.676)$ & $(0.002)$ & $(0.623)$ & $(0.002)$ \\
\hline $1.043 * * *$ & $0.017^{\phi}$ & $1.372 * * *$ & $0.015^{\phi}$ & $1.079 * * *$ & $0.010^{\phi}$ \\
\hline (0.229) & $(0.003)$ & $(0.270)$ & $(0.003)$ & $(0.287)$ & $(0.003)$ \\
\hline
\end{tabular}

Abbreviations- $B M I$ body mass index, ECD expanded criteria donor, $C M S$ Centers for Medicare and Medicaid Services, CoP Conditions of Participation. Standard errors are reported in parentheses. † Marginal effects are estimated using a simulation method similar to the Krinsky, Robb [61] and Krinsky, Robb [62] method used for elasticity calculations. We take 1000 draws from the parameter distribution and estimate the change in probability resulting from a $1 \%$ change in the covariates for continuous variables and a shift from 0 to 1 for binary variables in the regression. Our results allow to construct $95 \%$ confidence intervals that we use to estimate statistical significance. Inference: $* * * p<0.01, * * p<0.05,{ }^{*} p<0.1 ;{ }^{\phi}$ indicates statistically significant at $>95 \%$ level

We estimate our regression models using two choice sets dictated by the distribution of distances travelled by patients to their transplant centers of choice. The first, the restrictive choice set, includes centers within the 90th percentile of distances traveled (a 158-mile distance buffer) and the second expand the choice set to include centers within the 95th percentile of distances traveled (a 232-mile distance buffer). Our choice sets are at both ends of the distribution when compared with the 200-mile distance buffer specification utilized by Howard, Kaplan [36] and the results from the conditional logit models in our main specification are consistent with findings in Howard, Kaplan [36]. Nonetheless, our sorting equilibrium model results imply that their findings are mostly driven by center-level heterogeneity which is not accounted for in their study.

The differences between the two choice sets considered primarily result from the expansion of choices between these two models. These results coupled with those estimated when using the 75th percentile of distances suggest that one's assumption regarding the "true" choice set for a patient matters when estimating the role of information in this setting. In theory, restricted 
Table 6 The effect of regulatory-binding report cards on patient selection of a transplant center: first stage of the sorting equilibrium model with risk factor interaction terms

Panel A: 90th percentile of distances traveled (158-Mile Buffer)

\begin{tabular}{|c|c|c|c|c|c|c|}
\hline \multirow[b]{2}{*}{ Variable } & \multicolumn{2}{|c|}{$\begin{array}{l}\text { Either Graft or Patient } \\
\text { Survival Rate }\end{array}$} & \multicolumn{2}{|c|}{ Graft Survival Rate } & \multicolumn{2}{|c|}{ Patient Survival Rate } \\
\hline & Coeff. & Marg. Eff. $\dagger$ & Coeff. & Marg. Eff. & Coeff. & Marg.Eff. \\
\hline Distance & $\begin{array}{l}-57.004 * * * \\
(0.149)\end{array}$ & $\begin{array}{l}-1.223^{\phi} \\
(0.003)\end{array}$ & $\begin{array}{l}-56.937 * * * \\
(0.149)\end{array}$ & $\begin{array}{l}-1.222^{\phi} \\
(0.003)\end{array}$ & $\begin{array}{l}-56.954 * * * \\
(0.149)\end{array}$ & $\begin{array}{l}-1.222^{\phi} \\
(0.003)\end{array}$ \\
\hline Average age of patients & $8.295 * * *$ & $2.333^{\phi}$ & $7.576 * * *$ & $2.133^{\phi}$ & $7.562 * * *$ & $2.131^{\phi}$ \\
\hline Proportion of white patients & $\begin{array}{l}-5.259 * * * \\
(0.044)\end{array}$ & $\begin{array}{l}-1.260^{\phi} \\
(0.010)\end{array}$ & $\begin{array}{l}-4.904 * * * \\
(0.044)\end{array}$ & $\begin{array}{l}-1.175^{\phi} \\
(0.011)\end{array}$ & $\begin{array}{l}-5.098^{* * * *} \\
(0.044)\end{array}$ & $\begin{array}{l}-1.221^{\phi} \\
(0.011)\end{array}$ \\
\hline Proportion of black patients & $\begin{array}{l}-3.302 * * * \\
(0.047)\end{array}$ & $\begin{array}{l}-0.643^{\phi} \\
(0.009)\end{array}$ & $\begin{array}{l}-3.450 * * * \\
(0.047)\end{array}$ & $\begin{array}{l}-0.671^{\phi} \\
(0.010)\end{array}$ & $\begin{array}{l}-3.577 * * * \\
(0.047)\end{array}$ & $\begin{array}{l}-0.696^{\phi} \\
(0.010)\end{array}$ \\
\hline Proportion of female patients & $\begin{array}{l}-2.531 * * * \\
(0.076)\end{array}$ & $\begin{array}{l}-0.608^{\phi} \\
(0.018)\end{array}$ & $\begin{array}{l}-2.554 * * * \\
(0.076)\end{array}$ & $\begin{array}{l}-0.614^{\phi} \\
(0.018)\end{array}$ & $\begin{array}{l}-2.545 * * * \\
(0.076)\end{array}$ & $\begin{array}{l}-0.612^{\phi} \\
(0.019)\end{array}$ \\
\hline Average BMI of patients & $\begin{array}{l}8.355^{* * * *} \\
(0.156)\end{array}$ & $\begin{array}{l}1.287^{\phi} \\
(0.024)\end{array}$ & $\begin{array}{l}9.895 * * * \\
(0.156)\end{array}$ & $\begin{array}{l}1.524^{\phi} \\
(0.025)\end{array}$ & $\begin{array}{l}9.777 * * * * \\
(0.156)\end{array}$ & $\begin{array}{l}1.505^{\phi} \\
(0.024)\end{array}$ \\
\hline ECD transplants in past year & $\begin{array}{l}0.658^{* * * *} \\
(0.041)\end{array}$ & $\begin{array}{l}0.050^{\phi} \\
(0.003)\end{array}$ & $\begin{array}{l}0.704 * * * \\
(0.040)\end{array}$ & $\begin{array}{l}0.053^{\phi} \\
(0.003)\end{array}$ & $\begin{array}{l}0.575 * * * \\
(0.041)\end{array}$ & $\begin{array}{l}0.043^{\phi} \\
(0.003)\end{array}$ \\
\hline Proportion of highly sensitized patients & $\begin{array}{l}2.833 * * * \\
(0.139)\end{array}$ & $\begin{array}{l}0.076^{\phi} \\
(0.004)\end{array}$ & $\begin{array}{l}3.472 * * * \\
(0.138)\end{array}$ & $\begin{array}{l}0.093^{\phi} \\
(0.004)\end{array}$ & $\begin{array}{l}3.578 * * * * \\
(0.138)\end{array}$ & $\begin{array}{l}0.096^{\phi} \\
(0.004)\end{array}$ \\
\hline Proportion of patients with diabetes & $\begin{array}{l}5.963 * * * \\
(0.083)\end{array}$ & $\begin{array}{l}0.596^{\phi} \\
(0.008)\end{array}$ & $\begin{array}{l}5.726^{* * * *} \\
(0.082)\end{array}$ & $\begin{array}{l}0.573^{\phi} \\
(0.008)\end{array}$ & $\begin{array}{l}6.088^{* * * *} \\
(0.083)\end{array}$ & $\begin{array}{l}0.609^{\phi} \\
(0.008)\end{array}$ \\
\hline Annual kidney donors in donation area & $\begin{array}{l}2.432 * * * \\
(0.006)\end{array}$ & $\begin{array}{l}3.074^{\Phi} \\
(0.007)\end{array}$ & $\begin{array}{l}0.886 * * * \\
(0.006)\end{array}$ & $\begin{array}{l}1.108^{\phi} \\
(0.007)\end{array}$ & $\begin{array}{l}0.892 * * * * \\
(0.006)\end{array}$ & $\begin{array}{l}1.115^{\phi} \\
(0.007)\end{array}$ \\
\hline Negative report card $*$ ECD transplants in past year & $\begin{array}{l}0.451 \\
(0.102)\end{array}$ & $\begin{array}{l}0.032^{\phi} \\
(0.007)\end{array}$ & $\begin{array}{l}0.351 \\
(0.213)\end{array}$ & $\begin{array}{l}0.019 \\
(0.012)\end{array}$ & $\begin{array}{l}1.462 * * * \\
(0.115)\end{array}$ & $\begin{array}{l}0.114^{\phi} \\
(0.009)\end{array}$ \\
\hline Negative report card $*$ highly sensitized & $\begin{array}{l}1.269^{* *} \\
(0.347)\end{array}$ & $\begin{array}{l}0.037^{\phi} \\
(0.011)\end{array}$ & $\begin{array}{l}-1.016^{* *} \\
(0.445)\end{array}$ & $\begin{array}{l}-0.031^{\phi} \\
(0.013)\end{array}$ & $\begin{array}{l}1.733 * * * * \\
(0.410)\end{array}$ & $\begin{array}{l}0.053^{\phi} \\
(0.013)\end{array}$ \\
\hline Negative report card $*$ proportion with diabetes & $\begin{array}{l}-1.426 \\
(0.165)\end{array}$ & $\begin{array}{l}-0.159^{\phi} \\
(0.019)\end{array}$ & $\begin{array}{l}-0.304 \\
(0.198)\end{array}$ & $\begin{array}{l}-0.037 \\
(0.023)\end{array}$ & $\begin{array}{l}-1.506^{* * * *} \\
(0.229)\end{array}$ & $\begin{array}{l}-0.150^{\phi} \\
(0.024)\end{array}$ \\
\hline Post CMS CoP $*$ ECD transplants in past year & $\begin{array}{l}-0.737 * * * \\
(0.056)\end{array}$ & $\begin{array}{l}-0.060^{\phi} \\
(0.005)\end{array}$ & $\begin{array}{l}-0.802 * * * \\
(0.055)\end{array}$ & $\begin{array}{l}-0.065^{\phi} \\
(0.004)\end{array}$ & $\begin{array}{l}-0.645^{* * *} \\
(0.056)\end{array}$ & $\begin{array}{l}-0.052^{\phi} \\
(0.004)\end{array}$ \\
\hline Post CMS CoP * proportion of highly sensitized patients & $\begin{array}{l}-0.318 * * * \\
(0.185)\end{array}$ & $\begin{array}{l}-0.009 \\
(0.006)\end{array}$ & $\begin{array}{l}-1.422 * * * \\
(0.184)\end{array}$ & $\begin{array}{l}-0.040^{\phi} \\
(0.005)\end{array}$ & $\begin{array}{l}-1.298 * * * \\
(0.184)\end{array}$ & $\begin{array}{l}-0.037^{\Phi} \\
(0.006)\end{array}$ \\
\hline Post $\mathrm{CMS} \mathrm{CoP} *$ proportion with diabetes & $\begin{array}{l}-5.644 * * * \\
(0.098)\end{array}$ & $\begin{array}{l}-0.817^{\phi} \\
(0.013)\end{array}$ & $\begin{array}{l}-5.222 * * * \\
(0.097)\end{array}$ & $\begin{array}{l}-0.757^{\phi} \\
(0.014)\end{array}$ & $\begin{array}{l}-5.370^{* * *} \\
(0.098)\end{array}$ & $\begin{array}{l}-0.778^{\phi} \\
(0.014)\end{array}$ \\
\hline $\begin{array}{l}\text { Post CMS CoP } * \text { negative report card } * \text { ECD } \\
\text { transplants in past year }\end{array}$ & $\begin{array}{l}-1.651 * * * \\
(0.181)\end{array}$ & $\begin{array}{l}-0.108^{\phi} \\
(0.012)\end{array}$ & $\begin{array}{l}-0.825 * * * \\
(0.274)\end{array}$ & $\begin{array}{l}-0.054^{\phi} \\
(0.018)\end{array}$ & $\begin{array}{l}-3.246 * * * \\
(0.223)\end{array}$ & $\begin{array}{l}-0.210^{\phi} \\
(0.013)\end{array}$ \\
\hline Post CMS CoP * negative report card * highly sensitized & $\begin{array}{l}1.551 * * * \\
(0.454)\end{array}$ & $\begin{array}{l}0.054^{\Phi} \\
(0.015)\end{array}$ & $\begin{array}{l}4.896 * * * \\
(0.591)\end{array}$ & $\begin{array}{l}0.182^{\phi} \\
(0.022)\end{array}$ & $\begin{array}{l}2.253 * * * \\
(0.535)\end{array}$ & $\begin{array}{l}0.079^{\phi} \\
(0.018)\end{array}$ \\
\hline $\begin{array}{l}\text { Post CMS CoP } * \text { negative report card * } \\
\text { proportion with diabetes }\end{array}$ & $\begin{array}{l}-0.105 * * \\
(0.193)\end{array}$ & $\begin{array}{l}-0.015 \\
(0.032)\end{array}$ & $\begin{array}{l}-0.501 * * \\
(0.231)\end{array}$ & $\begin{array}{l}-0.088^{\phi} \\
(0.039)\end{array}$ & $\begin{array}{l}-0.056 \\
(0.260)\end{array}$ & $\begin{array}{l}-0.009 \\
(0.036)\end{array}$ \\
\hline $\begin{array}{l}\text { Observations } \\
\text { Log-Likelihood (0) } \\
\text { Log-Likelihood }\end{array}$ & $\begin{array}{l}199 \\
-37 \\
-24\end{array}$ & $\begin{array}{l}318 \\
468 \\
108\end{array}$ & & $\begin{array}{l}318 \\
468 \\
107\end{array}$ & $\begin{array}{r}196 \\
376 \\
-241\end{array}$ & \\
\hline
\end{tabular}

Panel B: 95th percentile of distances traveled (232-Mile Buffer)

\begin{tabular}{|c|c|c|c|c|c|c|}
\hline \multirow[b]{2}{*}{ Variable } & \multicolumn{2}{|c|}{$\begin{array}{l}\text { Either Graft or Patient } \\
\quad \text { Survival Rate }\end{array}$} & \multicolumn{2}{|c|}{ Graft Survival Rate } & \multicolumn{2}{|c|}{ Patient Survival Rate } \\
\hline & Coeff. & Marg. Eff. & Coeff. & Marg. Eff. & Coeff. & Marg.Eff. \\
\hline Distance & $\begin{array}{l}-47.825 * * * \\
(0.106)\end{array}$ & $\begin{array}{l}-1.331^{\phi} \\
(0.003)\end{array}$ & $\begin{array}{l}-47.846 * * * * \\
(0.106)\end{array}$ & $\begin{array}{l}-1.331^{\phi} \\
(0.003)\end{array}$ & $\begin{array}{l}-47.827 * * * \\
(0.106)\end{array}$ & $\begin{array}{l}-1.331^{\phi} \\
(0.003)\end{array}$ \\
\hline Average age of patients & $\begin{array}{l}7.665^{* * * *} \\
(0.179)\end{array}$ & $\begin{array}{l}2.258^{\phi} \\
(0.057)\end{array}$ & $\begin{array}{l}7.390 * * * \\
(0.179)\end{array}$ & $\begin{array}{l}2.181^{\phi} \\
(0.054)\end{array}$ & $\begin{array}{l}7.368 * * * \\
(0.179)\end{array}$ & $\begin{array}{l}2.177^{\phi} \\
(0.053)\end{array}$ \\
\hline Proportion of white patients & $\begin{array}{l}-3.529 * * * \\
(0.041)\end{array}$ & $\begin{array}{l}-0.894^{\phi} \\
(0.010)\end{array}$ & $\begin{array}{l}-3.664 * * * \\
(0.040)\end{array}$ & $\begin{array}{l}-0.927^{\phi} \\
(0.011)\end{array}$ & $\begin{array}{l}-3.473 * * * \\
(0.041)\end{array}$ & $\begin{array}{l}-0.880^{\phi} \\
(0.011)\end{array}$ \\
\hline Proportion of black patients & $\begin{array}{l}-2.130 * * * \\
(0.044)\end{array}$ & $\begin{array}{l}-0.434^{\phi} \\
(0.009)\end{array}$ & $\begin{array}{l}-2.349 * * * \\
(0.044)\end{array}$ & $\begin{array}{l}-0.478^{\phi} \\
(0.010)\end{array}$ & $\begin{array}{l}-2.090 * * * \\
(0.044)\end{array}$ & $\begin{array}{l}-0.426^{\phi} \\
(0.009)\end{array}$ \\
\hline Proportion of female patients & $\begin{array}{l}-2.464 * * * \\
(0.070)\end{array}$ & $\begin{array}{l}-0.621^{\phi} \\
(0.018)\end{array}$ & $\begin{array}{l}-2.486 * * * \\
(0.070)\end{array}$ & $\begin{array}{l}-0.627^{\phi} \\
(0.017)\end{array}$ & $\begin{array}{l}-2.480 * * * \\
(0.070)\end{array}$ & $\begin{array}{l}-0.626^{\phi} \\
(0.018)\end{array}$ \\
\hline Average BMI of patients & $\begin{array}{l}6.116^{* * * *} \\
(0.151)\end{array}$ & $\begin{array}{l}0.989^{\phi} \\
(0.024)\end{array}$ & $\begin{array}{l}7.432 * * * \\
(0.151)\end{array}$ & $\begin{array}{l}1.201^{\phi} \\
(0.025)\end{array}$ & $\begin{array}{l}6.779 * * * \\
(0.151)\end{array}$ & $\begin{array}{l}1.094^{\phi} \\
(0.024)\end{array}$ \\
\hline ECD transplants in past year & $\begin{array}{l}0.651 * * * \\
(0.039)\end{array}$ & $\begin{array}{l}0.051^{\phi} \\
(0.003)\end{array}$ & $\begin{array}{l}0.757 * * * \\
(0.038)\end{array}$ & $\begin{array}{l}0.060^{\phi} \\
(0.003)\end{array}$ & $\begin{array}{l}0.625^{* * * *} \\
(0.039)\end{array}$ & $\begin{array}{l}0.049^{\phi} \\
(0.003)\end{array}$ \\
\hline Proportion of highly sensitized patients & $\begin{array}{l}1.835 * * * \\
(0.128)\end{array}$ & $\begin{array}{l}0.052^{\phi} \\
(0.004)\end{array}$ & $\begin{array}{l}2.846 * * * \\
(0.128)\end{array}$ & $\begin{array}{l}0.081^{\phi} \\
(0.004)\end{array}$ & $\begin{array}{l}2.000^{* * * *} \\
(0.128)\end{array}$ & $\begin{array}{l}0.057^{\phi} \\
(0.003)\end{array}$ \\
\hline Proportion of patients with diabetes & $\begin{array}{l}5.598 * * * \\
(0.078)\end{array}$ & $\begin{array}{l}0.589^{\phi} \\
(0.008)\end{array}$ & $\begin{array}{l}5.399 * * * \\
(0.077)\end{array}$ & $\begin{array}{l}0.568^{\phi} \\
(0.008)\end{array}$ & $\begin{array}{l}5.489 * * * \\
(0.078)\end{array}$ & $\begin{array}{l}0.578^{\phi} \\
(0.008)\end{array}$ \\
\hline Annual kidney donors in donation area & $0.630 * * *$ & $0.810^{\phi}$ & $0.675^{* * *}$ & $0.868^{\phi}$ & $0.640 * * *$ & $0.823^{\phi}$ \\
\hline
\end{tabular}


Table 6 (continued)

\begin{tabular}{|c|c|c|c|c|c|c|}
\hline Negative report card $*$ ECD transplants in past year & $\begin{array}{l}(0.005) \\
0.394 * * * \\
(0.098)\end{array}$ & $\begin{array}{l}(0.006) \\
0.029^{\phi} \\
(0.008)\end{array}$ & $\begin{array}{l}(0.005) \\
0.491^{* *} \\
(0.202)\end{array}$ & $\begin{array}{l}(0.006) \\
0.028^{\phi} \\
(0.012)\end{array}$ & $\begin{array}{l}(0.005) \\
1.013 * * * \\
(0.109)\end{array}$ & $\begin{array}{l}(0.006) \\
0.082^{\phi} \\
(0.008)\end{array}$ \\
\hline Negative report card $*$ highly sensitized & $1.011 * * *$ & $\begin{array}{l}0.033^{\phi} \\
(0.011)\end{array}$ & $\begin{array}{l}-2.862 * * * \\
(0.404)\end{array}$ & $-0.094^{\phi}$ & $1.045^{* * * *}$ & $\begin{array}{l}0.035^{\phi} \\
(0.013)\end{array}$ \\
\hline Negative report card $*$ proportion with diabetes & $\begin{array}{l}-1.063 * * * \\
(0.155)\end{array}$ & $\begin{array}{l}-0.125^{\phi} \\
(0.019)\end{array}$ & $\begin{array}{l}0.136 \\
(0.187)\end{array}$ & $\begin{array}{l}0.018 \\
(0.023)\end{array}$ & $\begin{array}{l}-1.250^{* * * *} \\
(0.213)\end{array}$ & $\begin{array}{l}-0.131^{\phi} \\
(0.023)\end{array}$ \\
\hline Post CMS CoP * ECD transplants in past year & $\begin{array}{l}-0.582 * * * \\
(0.054)\end{array}$ & $\begin{array}{l}-0.049^{\phi} \\
(0.005)\end{array}$ & $\begin{array}{l}-0.809 \text { *** } \\
(0.053)\end{array}$ & $\begin{array}{l}-0.069^{\phi} \\
(0.004)\end{array}$ & $\begin{array}{l}-0.625 * * * \\
(0.054)\end{array}$ & $\begin{array}{l}-0.053^{\phi} \\
(0.004)\end{array}$ \\
\hline Post CMS CoP * proportion of highly sensitized patients & $\begin{array}{l}-0.073 \\
(0.171)\end{array}$ & $\begin{array}{l}-0.002^{\phi} \\
(0.005)\end{array}$ & $\begin{array}{l}-1.378 * * * \\
(0.170)\end{array}$ & $\begin{array}{l}-0.041^{\phi} \\
(0.005)\end{array}$ & $\begin{array}{l}-0.290^{*} \\
(0.170)\end{array}$ & $\begin{array}{l}-0.009 \\
(0.005)\end{array}$ \\
\hline Post $\mathrm{CMS} \mathrm{CoP} *$ proportion with diabetes & $\begin{array}{l}-5.170 * * * * \\
(0.093)\end{array}$ & $\begin{array}{l}-0.789^{\phi} \\
(0.013)\end{array}$ & $\begin{array}{l}-4.735 * * * \\
(0.092)\end{array}$ & $\begin{array}{l}-0.723^{\phi} \\
(0.014)\end{array}$ & $\begin{array}{l}-4.986 * * * * \\
(0.092)\end{array}$ & $\begin{array}{l}-0.761^{\phi} \\
(0.014)\end{array}$ \\
\hline Post CMS CoP * negative report card * ECD transplants in past year & $\begin{array}{l}-1.239 * * * * \\
(0.175)\end{array}$ & $\begin{array}{l}-0.083^{\phi} \\
(0.012)\end{array}$ & $\begin{array}{l}-1.154 * * * * \\
(0.263)\end{array}$ & $\begin{array}{l}-0.077^{\phi} \\
(0.018)\end{array}$ & $\begin{array}{l}-2.315 * * * * \\
(0.214)\end{array}$ & $\begin{array}{l}-0.156^{\phi} \\
(0.013)\end{array}$ \\
\hline Post CMS CoP $*$ negative report card $*$ highly sensitized & $\begin{array}{l}1.224 * * * \\
(0.417)\end{array}$ & $\begin{array}{l}0.045^{\Phi} \\
(0.015)\end{array}$ & $\begin{array}{l}6.932 * * * \\
(0.548)\end{array}$ & $\begin{array}{l}0.271^{\phi} \\
(0.021)\end{array}$ & $\begin{array}{l}1.916 * * * \\
(0.492)\end{array}$ & $\begin{array}{l}0.073^{\phi} \\
(0.018)\end{array}$ \\
\hline Post $\mathrm{CMS} \mathrm{CoP} *$ negative report card $*$ proportion with diabetes & $\begin{array}{l}-0.439 * * \\
(0.181)\end{array}$ & $\begin{array}{l}-0.072^{\phi} \\
(0.032)\end{array}$ & $\begin{array}{l}-1.657 * * * \\
(0.219)\end{array}$ & $\begin{array}{l}-0.302 \\
(0.039)\end{array}$ & $\begin{array}{l}-0.175 \\
(0.243)\end{array}$ & $\begin{array}{l}-0.028 \\
(0.035)\end{array}$ \\
\hline $\begin{array}{l}\text { Observations } \\
\text { Log-Likelihood (0) } \\
\text { Log-Likelihood }\end{array}$ & \multicolumn{2}{|c|}{$\begin{array}{c}206,477 \\
-488,607 \\
-274,984\end{array}$} & \multicolumn{2}{|c|}{$\begin{array}{c}206,477 \\
-488,607 \\
-274,970\end{array}$} & \multicolumn{2}{|c|}{$\begin{array}{c}206,477 \\
-488,607 \\
-274,982\end{array}$} \\
\hline
\end{tabular}

Abbreviations- $B M I$ body mass index, ECD expanded criteria donor, $C M S$ Centers for Medicare and Medicaid Services, CoP Conditions of Participation. Standard errors are reported in parentheses. $\uparrow$ Marginal effects are estimated using a simulation method similar to the Krinsky, Robb [61] and Krinsky, Robb [62] method used for elasticity calculations. We take 1000 draws from the parameter distribution and estimate the change in probability resulting from a $1 \%$ change in the covariates for continuous variables and a shift from 0 to 1 for binary variables in the regression. Our results allow to construct $95 \%$ confidence intervals that we use to estimate statistical significance. Inference: $* * * p<0.01, * * p<0.05, * p<0.1 ;{ }^{\phi}$ indicates statistically significant at $>95 \%$ level

choice-set models assume less informational flows whereas in larger choice-set models more information is present. Nonetheless results suggest that the impact of informational flows is already attained in our restricted choice set and more information beyond what already exists may not add any value to the patient's response. This finding raises the question of what would be the appropriate choice set assumption because that assumption substantially affects the impact of the binding regulation on the results.

Our findings in the sorting equilibrium model, showing that when the impact of the regulation is allowed to vary with changes in risk factors, patients are less likely to register at lowperforming centers post-CoP if these centers conducted a higher number of ECD transplants, have important implications for policy. These results provide some evidence for risk aversion of "more aggressive" centers following the regulation and suggest that patients are more likely to end up at centers that are less aggressive with their organ utilization policies, potentially generating longer waiting times for these patients. Moreover, gravitation toward centers that have a higher rate of highly sensitized patients implies further stress for these centers because such patients are more difficult to find suitable organ matches and they experience a higher rate of graft survival failure, further exacerbating the centers' risk profile.

Our study has several limitations. First, we only study the binding nature of report cards in patient selection of kidney transplant centers, though the CMS CoPs also apply to liver transplant centers. Nonetheless, our analyses have important implications because kidney is the most transplanted solid organ in the U.S. [65] and Medicare fee-for-service spending for beneficiaries with ESRD _ counting 511,270 beneficiaries in 2016 and representing less than $1 \%$ of total Medicare beneficiariesrose from $\$ 33.8$ billion to $\$ 35.4$ billion from 2015 to 2016 ( $7.2 \%$ of total Medicare spending) [11]. Second, patients' decisions to get on a waiting list may also depend on their willingness to pursue a transplantation, medical limitations, financial concerns, timely referral to a transplant center, and health literacy (e.g. information obtained from their referring physician such as the history of a center's deactivations, information on the potential benefits of the evaluation and transplantation process) [5-7]. In our study focusing on revealed (i.e. actual observed) preferences, we are unable to measure or account for such factors with the registry data used but rather examine data available for those that successfully completed the evaluation process to be placed on the waiting list for transplantation. Further studies surveying patients may help better understand their preferences about the transplantation process and better gauge consumer choice in response to quality ratings. Third, we investigate the impact of the CMS CoPs on selection of transplant centers in the short run and study variation in these effects across different choice set assumptions. However, the CMS CoPs may also have long-run effects on centers' risk aversion of high-risk patients. Fourth, we are unable to directly measure the extent to which potential provider's riskaversion may influence patient sorting in the post-CMS regulation period. However, there is increasing evidence alluding to this unintended and problematic provider behavior [19, 21-23]. Additionally, our findings suggesting sorting away from lowperforming centers that conduct more ECD transplants and 
Table 7 The effect of regulatory-binding report cards on patient selection of a transplant center: second stage of the sorting equilibrium model with risk factor interaction terms

\begin{tabular}{|c|c|c|c|c|c|c|}
\hline \multirow[b]{2}{*}{ Variable } & \multicolumn{3}{|c|}{ 90th Percentile of Distances Traveled (158-Mile Buffer) } & \multicolumn{3}{|c|}{ 95th Percentile of Distances Traveled (232-Mile Buffer) } \\
\hline & $\begin{array}{l}\text { Either Graft or Patient } \\
\text { Survival Rate } \\
\text { Coeff. }\end{array}$ & $\begin{array}{l}\text { Graft Survival } \\
\text { Rate } \\
\text { Coeff. }\end{array}$ & $\begin{array}{l}\text { Patient Survival } \\
\text { Rate } \\
\text { Coeff. }\end{array}$ & $\begin{array}{l}\text { Either Graft or Patient } \\
\text { Survival Rate } \\
\text { Coeff. }\end{array}$ & $\begin{array}{l}\text { Graft Survival } \\
\text { Rate } \\
\text { Coeff. }\end{array}$ & $\begin{array}{l}\text { Patient Survival } \\
\text { Rate } \\
\text { Coeff. }\end{array}$ \\
\hline Constant & $\begin{array}{l}9.880 * * * \\
(1.025)\end{array}$ & $\begin{array}{l}8.230 * * * \\
(0.933)\end{array}$ & $\begin{array}{l}8.249 * * * \\
(0.937)\end{array}$ & $\begin{array}{l}8.364 * * * \\
(1.204)\end{array}$ & $\begin{array}{l}8.487 * * * \\
(1.211)\end{array}$ & $\begin{array}{l}8.509 * * * \\
(1.208)\end{array}$ \\
\hline Average age of patients & $\begin{array}{l}-12.428 * * * \\
(1.883)\end{array}$ & $\begin{array}{l}-10.931 * * * \\
(1.718)\end{array}$ & $\begin{array}{l}-11.218 * * * \\
(1.724)\end{array}$ & $\begin{array}{l}-4.984 * * * \\
(2.223)\end{array}$ & $\begin{array}{l}-4.482 * * * \\
(2.233)\end{array}$ & $\begin{array}{l}-4.753 * * * \\
(2.227)\end{array}$ \\
\hline Proportion of white patients & $\begin{array}{l}2.774 * * * \\
(0.281)\end{array}$ & $\begin{array}{l}2.752 * * * \\
(0.261)\end{array}$ & $\begin{array}{l}2.819 * * * \\
(0.262)\end{array}$ & $\begin{array}{l}4.940 * * * \\
(0.336)\end{array}$ & $\begin{array}{l}5.115^{* * * *} \\
(0.338)\end{array}$ & $\begin{array}{l}4.917 * * * \\
(0.337)\end{array}$ \\
\hline Proportion of black patients & $\begin{array}{l}1.008 * * * \\
(0.271)\end{array}$ & $\begin{array}{l}1.192 * * * \\
(0.247)\end{array}$ & $\begin{array}{l}1.209 * * * \\
(0.248)\end{array}$ & $\begin{array}{l}2.014 * * * \\
(0.320)\end{array}$ & $\begin{array}{l}2.200 * * * \\
(0.321)\end{array}$ & $\begin{array}{l}1.983 * * * \\
(0.320)\end{array}$ \\
\hline Proportion of female patients & $\begin{array}{l}2.205 * * * \\
(0.725)\end{array}$ & $\begin{array}{l}2.657 * * * \\
(0.664)\end{array}$ & $\begin{array}{l}2.630 * * * \\
(0.666)\end{array}$ & $\begin{array}{l}1.041 \\
(0.845)\end{array}$ & $\begin{array}{l}1.062 \\
(0.851)\end{array}$ & $\begin{array}{l}0.999 \\
(0.847)\end{array}$ \\
\hline Average BMI of patients & $\begin{array}{l}-8.580 * * * \\
(2.551)\end{array}$ & $\begin{array}{l}-10.269 * * * \\
(2.320)\end{array}$ & $\begin{array}{l}-9.781 * * * \\
(2.328)\end{array}$ & $\begin{array}{l}-15.232 * * * \\
(2.995)\end{array}$ & $\begin{array}{l}-17.030 * * * \\
(3.012)\end{array}$ & $\begin{array}{l}-15.895^{* * *} \\
(3.001)\end{array}$ \\
\hline ECD transplants in past year & $\begin{array}{l}6.299 * * * \\
(0.555)\end{array}$ & $\begin{array}{l}5.855 * * * \\
(0.513)\end{array}$ & $\begin{array}{l}5.915 * * * \\
(0.513)\end{array}$ & $\begin{array}{l}6.480 * * * \\
(0.666)\end{array}$ & $\begin{array}{l}6.426 * * * \\
(0.670)\end{array}$ & $\begin{array}{l}6.545 * * * \\
(0.667)\end{array}$ \\
\hline $\begin{array}{l}\text { Proportion of highly } \\
\text { sensitized patients }\end{array}$ & $\begin{array}{l}-8.060 * * * \\
(1.063)\end{array}$ & $\begin{array}{l}-7.114 * * * \\
(0.970)\end{array}$ & $\begin{array}{l}-7.291 * * * \\
(0.974)\end{array}$ & $\begin{array}{l}-6.843 * * * \\
(1.253)\end{array}$ & $\begin{array}{l}-7.188 * * * \\
(1.261)\end{array}$ & $\begin{array}{l}-6.814 * * * \\
(1.257)\end{array}$ \\
\hline $\begin{array}{l}\text { Proportion of patients } \\
\text { with diabetes }\end{array}$ & $\begin{array}{l}-3.938 * * * \\
(0.605)\end{array}$ & $\begin{array}{l}-3.826 * * * \\
(0.552)\end{array}$ & $\begin{array}{l}-4.008 * * * \\
(0.554)\end{array}$ & $\begin{array}{l}-7.425 * * * \\
(0.712)\end{array}$ & $\begin{array}{l}-7.693 * * * \\
(0.717)\end{array}$ & $\begin{array}{l}-7.549 * * * \\
(0.713)\end{array}$ \\
\hline $\begin{array}{l}\text { Annual kidney donors } \\
\text { in donation area }\end{array}$ & $\begin{array}{l}-1.810 * * * \\
(0.055)\end{array}$ & $\begin{array}{l}-0.664 * * * \\
(0.047)\end{array}$ & $\begin{array}{l}-0.670 * * * \\
(0.047)\end{array}$ & $\begin{array}{l}-0.612 * * * \\
(0.060)\end{array}$ & $\begin{array}{l}-0.656^{* * * *} \\
(0.061)\end{array}$ & $\begin{array}{l}-0.634 * * * \\
(0.060)\end{array}$ \\
\hline Negative report card & $\begin{array}{l}0.005 \\
(0.215)\end{array}$ & $\begin{array}{l}0.172 \\
(0.229)\end{array}$ & $\begin{array}{l}-0.232 \\
(0.244)\end{array}$ & $\begin{array}{l}-0.120 \\
(0.253)\end{array}$ & $\begin{array}{l}0.094 \\
(0.298)\end{array}$ & $\begin{array}{l}-0.317 \\
(0.316)\end{array}$ \\
\hline Post CMS CoP & $\begin{array}{l}-2.260 * * * \\
(0.147)\end{array}$ & $\begin{array}{l}-2.729 * * * \\
(0.132)\end{array}$ & $\begin{array}{l}-2.745 * * * \\
(0.132)\end{array}$ & $\begin{array}{l}-4.616^{* * *} \\
(0.172)\end{array}$ & $\begin{array}{l}-4.559 * * * \\
(0.172)\end{array}$ & $\begin{array}{l}-4.657 * * * \\
(0.170)\end{array}$ \\
\hline $\begin{array}{l}\text { Negative report card* } \\
\text { Post CMS CoP }\end{array}$ & $\begin{array}{l}0.039 \\
(0.299)\end{array}$ & $\begin{array}{l}-0.310 \\
(0.316)\end{array}$ & $\begin{array}{l}0.555 \\
(0.345)\end{array}$ & $\begin{array}{l}0.176 \\
(0.353)\end{array}$ & $\begin{array}{l}-0.389 \\
(0.411)\end{array}$ & $\begin{array}{l}0.802 \\
(0.445)\end{array}$ \\
\hline Shares $(\rho) \dagger$ & $\begin{array}{l}-49.114 * * * \\
(11.092)\end{array}$ & $\begin{array}{l}-28.651^{* * *} \\
(11.823)\end{array}$ & $\begin{array}{l}-29.906 * * \\
(11.498)\end{array}$ & $\begin{array}{l}79.816^{* * *} \\
(15.691)\end{array}$ & $\begin{array}{l}83.407 * * * \\
(15.768)\end{array}$ & $\begin{array}{l}82.702 * * * \\
(15.670)\end{array}$ \\
\hline Observations & 3304 & 3304 & 3304 & 3308 & 3308 & 3308 \\
\hline R-squared & 0.519 & 0.452 & 0.451 & 0.531 & 0.536 & 0.533 \\
\hline
\end{tabular}

Abbreviations- $B M I$ body mass index, ECD expanded criteria donor, $C M S$ Centers for Medicare and Medicaid Services, CoP Conditions of Participation. Standard errors are reported in parentheses. $†$ The parameter $\rho$ is the share of patients that have selected a particular transplant center in a particular time period and the corresponding coefficient reported captures the degree of congestion $(-)$ or agglomeration $(+)$. Inference: $* * * p<0.01, * *$ $p<0.05, * p<0.1$

"worsened" patient matching if low-performing centers have higher proportions of higher-risk patients post-regulation call for more consideration. These findings should encourage policy makers to consider improving incentives for low-performing centers that implement innovative techniques and use lower quality organs to reduce the gap between the demand and supply for transplantation.

Our results should not be construed to indicate that adding a regulatory constraint would not increase the quality of healthcare at transplant centers. They merely indicate that overall patient sorting responds to the quality information similarly if there is a binding regulation or not. In light of the results in the sorting equilibrium model and other results on the association between the CMS CoP regulation and changes in the trends of kidney transplantation $[18,69,70]$, we can conclude that the regulation has a more noticeable impact on average on the supply side of the market with a substantial decrease in transplant volume, and increased organ discard rates and waiting times to 
transplantation than it does on overall patient volume. Recent changes to flagging criteria based on Bayesian methods, for accurately assessing performance of transplant centers [71], have resulted in fewer small-volume transplant programs $(<10$ transplants per 2.5 year period) being flagged for low-performance. This reduces potential "unfairness" of the evaluation method investigated in our study toward smaller programs and may reduce risk aversion toward higher risk patients or donors, potentially increasing access for higher-risk patients in these programs. Moreover, with the recent addition of pre-transplant metrics to report cards, informing patients on the likelihood of undergoing a transplant at a particular center, and the move from a 3-tier to a 5tier quality rating of centers $[8,72]$ program-specific report cards could further influence patient sorting across centers. Further addressing concerns about the CMS CoPs becoming increasingly stringent and transplant centers potentially discarding organs, the CMS updated guidelines for solid transplant programs outcome thresholds in 2016, putting programs with outcomes (deaths or graft failures) above $185 \%(O / E>1.85)$-rather than $150 \%$ as in the $2007 \mathrm{CMS} \mathrm{CoPs}$ - at risk for decertification [73,
74]. It is important to further explore the impact of the revised CMS CoP regulations on demand and supply of transplantation following improvements in center performance assessment methodology. Nonetheless, the COVID-19 pandemic comes with new and greater challenges for the U.S. practice of transplantation as many transplantation programs have been suspended or working with operational restrictions and organ donation has declined [75, 76], whereas the list of people waiting for transplants continues to grow.

Acknowledgments We are grateful to the United Network for Organ Sharing (UNOS), as the contractor for the Organ Procurement and Transplantation Network (OPTN), for providing the data. The interpretation and reporting of these data are the responsibility of the authors and in no way should be seen as an official policy of or interpretation by the OPTN or the U.S. Government.

\section{Compliance with ethical standards}

Conflict of interest The authors have no conflicts of interest to report.

\section{Appendix}
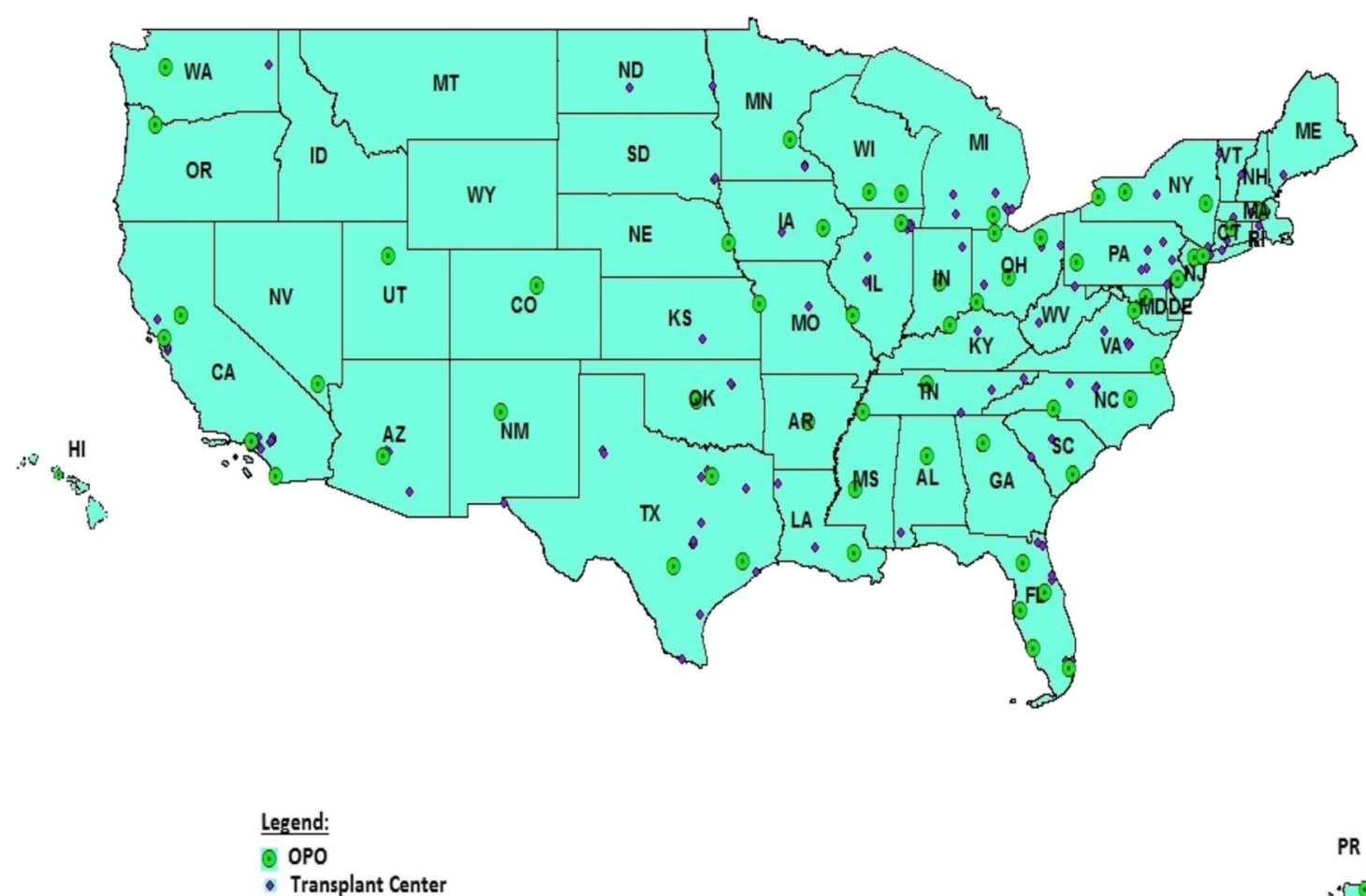

PR

- Transplant Center

Fig. 1 Distribution of Organ Procurement Organization (OPOs) and Transplant Centers across the United States by 2010 
Table 8 The effect of regulatory-binding report cards on patient selection of a transplant center: first stage of the sorting equilibrium model

75th Percentile of Distances Traveled (74-Mile Buffer)

\begin{tabular}{|c|c|c|}
\hline \multirow[b]{2}{*}{ Variable } & & \\
\hline & Coeff. & Marg. Eff. $\dagger$ \\
\hline Distance & $\begin{array}{l}-94.538^{* * *} \\
(0.389)\end{array}$ & $\begin{array}{l}-1.028^{\phi} \\
(0.004)\end{array}$ \\
\hline Average age of patients & $\begin{array}{l}10.947 * * * \\
(0.220)\end{array}$ & $\begin{array}{l}2.729^{\phi} \\
(0.053)\end{array}$ \\
\hline Proportion of white patients & $\begin{array}{l}-5.857 * * * \\
(0.052)\end{array}$ & $\begin{array}{l}-1.187^{\phi} \\
(0.011)\end{array}$ \\
\hline Proportion of black patients & $\begin{array}{l}-4.192 * * * \\
(0.054)\end{array}$ & $\begin{array}{l}-0.723^{\phi} \\
(0.010)\end{array}$ \\
\hline Proportion of female patients & $\begin{array}{l}-2.621 * * * \\
(0.091)\end{array}$ & $\begin{array}{l}-0.555^{\phi} \\
(0.019)\end{array}$ \\
\hline Average BMI of patients & $\begin{array}{l}7.882 * * * \\
(0.172)\end{array}$ & $\begin{array}{l}1.065^{\phi} \\
(0.022)\end{array}$ \\
\hline ECD transplants in past year & $\begin{array}{l}0.669 * * * \\
(0.032)\end{array}$ & $\begin{array}{l}0.046^{\phi} \\
(0.002)\end{array}$ \\
\hline Proportion of highly sensitized patients & $\begin{array}{l}2.431 * * * \\
(0.121)\end{array}$ & $\begin{array}{l}0.053^{\phi} \\
(0.003)\end{array}$ \\
\hline Proportion of patients with diabetes & $\begin{array}{l}3.112 * * * \\
(0.058)\end{array}$ & $\begin{array}{l}0.271^{\phi} \\
(0.005)\end{array}$ \\
\hline Annual kidney donors in donation area & $\begin{array}{l}2.091 * * * \\
(0.009)\end{array}$ & $\begin{array}{l}2.462^{\phi} \\
(0.011)\end{array}$ \\
\hline Observations & & \\
\hline Log-Likelihood (0) & & \\
\hline Log-Likelihood & & \\
\hline
\end{tabular}

Abbreviations- $B M I$ body mass index, ECD expanded criteria donor, CMS Centers for Medicare and Medicaid Services, CoP Conditions of Participation. Standard errors are reported in parentheses. † Marginal effects are estimated using a simulation method similar to the Krinsky, Robb [62] and Krinsky, Robb [63] method used for elasticity calculations. We take 1000 draws from the parameter distribution and estimate the change in probability resulting from a $1 \%$ change in the covariates for continuous variables and a shift from 0 to 1 for binary variables in the regression. Our results allow to construct $95 \%$ confidence intervals that we use to estimate statistical significance. Inference: $* * * p<0.01, * * p<0.05,{ }^{*} p<0.1{ }^{\phi}$ indicates statistically significant at $>95 \%$ level 
Table 9 The effect of regulatory-binding report cards on patient selection of a transplant center: second stage of the sorting equilibrium model

75th Percentile of Distances Traveled (74-Mile Buffer)

\begin{tabular}{|c|c|c|c|}
\hline \multirow{2}{*}{ Variable } & \\
\hline & $\begin{array}{l}\text { Either Graft or Patient } \\
\text { Survival Rate } \\
\text { Coeff. }\end{array}$ & $\begin{array}{l}\text { Graft Survival Rate } \\
\text { Coeff. }\end{array}$ & $\begin{array}{l}\text { Patient Survival Rate } \\
\text { Coeff. }\end{array}$ \\
\hline Constant & $\begin{array}{l}10.431 * * * \\
(1.227)\end{array}$ & $\begin{array}{l}10.432^{* * *} \\
(1.227)\end{array}$ & $\begin{array}{l}10.453 * * * \\
(1.227)\end{array}$ \\
\hline Average age of patients & $\begin{array}{l}-6.811 * * * \\
(2.256)\end{array}$ & $\begin{array}{l}-6.768 * * * \\
(2.255)\end{array}$ & $\begin{array}{l}-6.786^{* * * *} \\
(2.254)\end{array}$ \\
\hline Proportion of white patients & $\begin{array}{l}1.617 * * * \\
(0.335)\end{array}$ & $\begin{array}{l}1.617 * * * \\
(0.335)\end{array}$ & $\begin{array}{l}1.605 * * * \\
(0.335)\end{array}$ \\
\hline Proportion of black patients & $\begin{array}{l}-0.864 * * * \\
(0.330)\end{array}$ & $\begin{array}{l}-0.870^{* * *} \\
(0.330)\end{array}$ & $\begin{array}{l}-0.881 * * * \\
(0.330)\end{array}$ \\
\hline Proportion of female patients & $\begin{array}{l}2.960 * * * \\
(0.880)\end{array}$ & $\begin{array}{l}2.949 * * * \\
(0.881)\end{array}$ & $\begin{array}{l}2.901 * * * \\
(0.879)\end{array}$ \\
\hline Average BMI of patients & $\begin{array}{l}-12.715^{* * * *} \\
(3.045)\end{array}$ & $\begin{array}{l}-12.778 * * * \\
(3.040)\end{array}$ & $\begin{array}{l}-12.716^{* * *} \\
(3.041)\end{array}$ \\
\hline ECD transplants in past year & $\begin{array}{l}8.896^{* * * *} \\
(0.868)\end{array}$ & $\begin{array}{l}8.876 * * * \\
(0.868)\end{array}$ & $\begin{array}{l}8.956 * * * \\
(0.867)\end{array}$ \\
\hline Proportion of highly sensitized patients & $\begin{array}{l}-2.680 * * \\
(1.274)\end{array}$ & $\begin{array}{l}-2.661 * * \\
(1.274)\end{array}$ & $\begin{array}{l}-2.662 * * \\
(1.273)\end{array}$ \\
\hline Proportion of patients with diabetes & $\begin{array}{l}-8.537 * * * \\
(0.735)\end{array}$ & $\begin{array}{l}-8.536^{* * * *} \\
(0.735)\end{array}$ & $\begin{array}{l}-8.533 * * * \\
(0.734)\end{array}$ \\
\hline Annual kidney donors in donation area & $\begin{array}{l}-1.326^{* * *} \\
(0.061)\end{array}$ & $\begin{array}{l}-1.325^{* * *} \\
(0.061)\end{array}$ & $\begin{array}{l}-1.333 * * * \\
(0.060)\end{array}$ \\
\hline Negative report card & $\begin{array}{l}-0.132 \\
(0.258)\end{array}$ & $\begin{array}{l}-0.080 \\
(0.301)\end{array}$ & $\begin{array}{l}-0.092 \\
(0.321)\end{array}$ \\
\hline Post CMS CoP & $\begin{array}{l}-1.074 * * * \\
(0.174)\end{array}$ & $\begin{array}{l}-1.064 * * * \\
(0.172)\end{array}$ & $\begin{array}{l}-1.099 * * * \\
(0.171)\end{array}$ \\
\hline Negative report card*post CMS CoP & $\begin{array}{l}-0.017 \\
(0.359)\end{array}$ & $\begin{array}{l}-0.141 \\
(0.416)\end{array}$ & $\begin{array}{l}0.275 \\
(0.451)\end{array}$ \\
\hline Shares $(\rho) \dagger$ & $\begin{array}{l}-62.515^{* * * *} \\
(14.560)\end{array}$ & $\begin{array}{l}-62.275 * * * \\
(14.544)\end{array}$ & $\begin{array}{l}-62.585^{* * * *} \\
(14.532)\end{array}$ \\
\hline Observations & 3294 & 3294 & 3294 \\
\hline R-squared & 0.348 & 0.348 & 0.348 \\
\hline
\end{tabular}

Abbreviations- $B M I$ body mass index, ECD expanded criteria donor, CMS Centers for Medicare and Medicaid Services, CoP Conditions of Participation. Standard errors are reported in parentheses. $\uparrow$ The parameter $\rho$ is the share of patients that have selected a particular transplant center in a particular time period and the corresponding coefficient reported captures the degree of congestion $(-)$ or agglomeration $(+)$. Inference: $* * * p<0.01, * *$ $p<0.05, * p<0.1$ 
Table 10 The effect of regulatory-binding report cards on patient selection of a transplant center: first stage of the sorting equilibrium model with risk factor interaction terms

75th Percentile of Distances Traveled (74-Mile Buffer)

\begin{tabular}{|c|c|c|c|c|c|c|}
\hline \multirow[b]{2}{*}{ Variable } & \multicolumn{2}{|c|}{$\begin{array}{l}\text { Either Graft or Patient } \\
\text { Survival Rate }\end{array}$} & \multicolumn{2}{|c|}{ Graft Survival Rate } & \multicolumn{2}{|c|}{ Patient Survival Rate } \\
\hline & Coeff. & Marg. Eff. $\dagger$ & Coeff. & Marg. Eff. & Coeff. & Marg.Eff \\
\hline Distance & $\begin{array}{l}-94.577 * * * \\
(0.390)\end{array}$ & $\begin{array}{l}-1.029^{\phi} \\
(0.005)\end{array}$ & $\begin{array}{l}-94.565^{* * *} \\
(0.390)\end{array}$ & $\begin{array}{l}-1.028^{\phi} \\
(0.004)\end{array}$ & $\begin{array}{l}-94.564 * * * \\
(0.390)\end{array}$ & $\begin{array}{l}-1.028^{\phi} \\
(0.004)\end{array}$ \\
\hline Average age of patients & $\begin{array}{l}9.934 * * * \\
(0.224)\end{array}$ & $\begin{array}{l}2.473^{\phi} \\
(0.059)\end{array}$ & $\begin{array}{l}10.123 * * * \\
(0.225)\end{array}$ & $\begin{array}{l}2.526^{\phi} \\
(0.058)\end{array}$ & $\begin{array}{l}9.705 * * * \\
(0.224)\end{array}$ & $\begin{array}{l}2.423^{\phi} \\
(0.058)\end{array}$ \\
\hline Proportion of white patients & $\begin{array}{l}-6.349 * * * \\
(0.052)\end{array}$ & $\begin{array}{c}-1.286^{\phi} \\
(0.010)\end{array}$ & $\begin{array}{l}-6.230 * * * \\
(0.052)\end{array}$ & $\begin{array}{l}-1.262^{\phi} \\
(0.011)\end{array}$ & $\begin{array}{l}-6.229 * * * \\
(0.052)\end{array}$ & $\begin{array}{l}-1.261^{\phi} \\
(0.012)\end{array}$ \\
\hline Proportion of black patients & $\begin{array}{l}-4.927 * * * \\
(0.055)\end{array}$ & $\begin{array}{l}-0.849^{\phi} \\
(0.010)\end{array}$ & $\begin{array}{l}-4.772 * * * \\
(0.055)\end{array}$ & $\begin{array}{l}-0.822^{\phi} \\
(0.010)\end{array}$ & $\begin{array}{l}-4.817 * * * \\
(0.055)\end{array}$ & $\begin{array}{l}-0.830^{\phi} \\
(0.010)\end{array}$ \\
\hline Proportion of female patients & $\begin{array}{l}-2.724 * * * \\
(0.092)\end{array}$ & $\begin{array}{l}-0.576^{\phi} \\
(0.020)\end{array}$ & $\begin{array}{l}-2.740 * * * \\
(0.092)\end{array}$ & $\begin{array}{l}-0.580^{\phi} \\
(0.019)\end{array}$ & $\begin{array}{l}-2.737 * * * \\
(0.091)\end{array}$ & $\begin{array}{l}-0.580^{\phi} \\
(0.020)\end{array}$ \\
\hline Average BMI of patients & $\begin{array}{l}8.868 * * * \\
(0.174)\end{array}$ & $\begin{array}{l}1.198^{\phi} \\
(0.023)\end{array}$ & $\begin{array}{l}8.473 * * * \\
(0.173)\end{array}$ & $\begin{array}{l}1.144^{\phi} \\
(0.025)\end{array}$ & $\begin{array}{l}9.125 * * * \\
(0.174)\end{array}$ & $\begin{array}{l}1.231^{\phi} \\
(0.023)\end{array}$ \\
\hline ECD transplants in past year & $\begin{array}{l}0.874 * * * \\
(0.048)\end{array}$ & $\begin{array}{l}0.060^{\phi} \\
(0.003)\end{array}$ & $\begin{array}{l}1.042 * * * \\
(0.046)\end{array}$ & $\begin{array}{l}0.071^{\phi} \\
(0.003)\end{array}$ & $\begin{array}{l}0.888 * * * \\
(0.048)\end{array}$ & $\begin{array}{l}0.060^{\phi} \\
(0.003)\end{array}$ \\
\hline Proportion of highly sensitized patients & $\begin{array}{l}4.541 * * * \\
(0.176)\end{array}$ & $\begin{array}{l}0.100^{\phi} \\
(0.004)\end{array}$ & $\begin{array}{l}4.447 * * * \\
(0.175)\end{array}$ & $\begin{array}{l}0.098^{\phi} \\
(0.004)\end{array}$ & $\begin{array}{l}4.024 * * * \\
(0.175)\end{array}$ & $\begin{array}{l}0.088^{\phi} \\
(0.004)\end{array}$ \\
\hline Proportion of patients with diabetes & $\begin{array}{l}5.868 * * * \\
(0.097)\end{array}$ & $\begin{array}{l}0.511^{\phi} \\
(0.008)\end{array}$ & $\begin{array}{l}5.655 * * * \\
(0.096)\end{array}$ & $\begin{array}{l}0.493^{\phi} \\
(0.008)\end{array}$ & $\begin{array}{l}5.849 * * * \\
(0.097)\end{array}$ & $\begin{array}{l}0.509^{\phi} \\
(0.008)\end{array}$ \\
\hline Annual kidney donors in donation area & $\begin{array}{l}1.997 * * * \\
(0.009)\end{array}$ & $\begin{array}{l}2.350^{\phi} \\
(0.011)\end{array}$ & $\begin{array}{l}1.998 * * * \\
(0.009)\end{array}$ & $\begin{array}{l}2.351^{\phi} \\
(0.011)\end{array}$ & $\begin{array}{l}2.003 * * * \\
(0.009)\end{array}$ & $\begin{array}{l}2.357^{\phi} \\
(0.010)\end{array}$ \\
\hline Negative report card * ECD transplants in past year & $\begin{array}{l}1.318 * * * \\
(0.117)\end{array}$ & $\begin{array}{l}0.087^{\phi} \\
(0.008)\end{array}$ & $\begin{array}{l}1.794 * * * \\
(0.254)\end{array}$ & $\begin{array}{l}0.095^{\phi} \\
(0.013)\end{array}$ & $\begin{array}{l}2.338 * * * \\
(0.135)\end{array}$ & $\begin{array}{l}0.167^{\phi} \\
(0.009)\end{array}$ \\
\hline Negative report card $*$ Highly sensitized & $\begin{array}{l}-3.073 * * * \\
(0.453)\end{array}$ & $\begin{array}{l}-0.072^{\phi} \\
(0.011)\end{array}$ & $\begin{array}{l}-6.123 * * * \\
(0.571)\end{array}$ & $\begin{array}{l}-0.158^{\phi} \\
(0.014)\end{array}$ & $\begin{array}{l}2.668 * * * \\
(0.557)\end{array}$ & $\begin{array}{l}0.063^{\phi} \\
(0.013)\end{array}$ \\
\hline Negative report card $*$ proportion with diabetes & $\begin{array}{l}-1.504 * * * \\
(0.203)\end{array}$ & $\begin{array}{l}-0.149^{\phi} \\
(0.020)\end{array}$ & $\begin{array}{l}0.553 * * \\
(0.246)\end{array}$ & $\begin{array}{l}0.060^{\phi} \\
(0.026)\end{array}$ & $\begin{array}{l}-4.391 * * * \\
(0.295)\end{array}$ & $\begin{array}{l}-0.383^{\phi} \\
(0.026)\end{array}$ \\
\hline Post CMS CoP $*$ ECD transplants in past year & $\begin{array}{l}-0.623 * * * \\
(0.066)\end{array}$ & $\begin{array}{l}-0.046^{\phi} \\
(0.005)\end{array}$ & $\begin{array}{l}-0.816^{* * * *} \\
(0.065)\end{array}$ & $\begin{array}{l}-0.060^{\phi} \\
(0.005)\end{array}$ & $\begin{array}{l}-0.588^{* * * *} \\
(0.066)\end{array}$ & $\begin{array}{l}-0.043^{\phi} \\
(0.005)\end{array}$ \\
\hline Post CMS CoP * proportion of highly sensitized patients & $\begin{array}{l}-3.074 * * * \\
(0.234)\end{array}$ & $\begin{array}{l}-0.071^{\phi} \\
(0.006)\end{array}$ & $\begin{array}{l}-2.762 * * * \\
(0.232)\end{array}$ & $\begin{array}{l}-0.064^{\phi} \\
(0.006)\end{array}$ & $\begin{array}{l}-2.514 * * * \\
(0.232)\end{array}$ & $\begin{array}{l}-0.058^{\phi} \\
(0.006)\end{array}$ \\
\hline Post CMS CoP $*$ proportion with diabetes & $\begin{array}{l}-5.051 * * * \\
(0.115)\end{array}$ & $\begin{array}{l}-0.638^{\phi} \\
(0.014)\end{array}$ & $\begin{array}{l}-4.863 * * * \\
(0.113)\end{array}$ & $\begin{array}{l}-0.614^{\phi} \\
(0.014)\end{array}$ & $\begin{array}{l}-4.987 * * * \\
(0.114)\end{array}$ & $\begin{array}{l}-0.630^{\phi} \\
(0.014)\end{array}$ \\
\hline Post CMS CoP $*$ negative report card $*$ ECD transplants in past year & $\begin{array}{l}-2.338 * * * \\
(0.202)\end{array}$ & $\begin{array}{l}-0.144^{\phi} \\
(0.013)\end{array}$ & $\begin{array}{l}-2.367 * * * \\
(0.316)\end{array}$ & $\begin{array}{l}-0.153^{\phi} \\
(0.020)\end{array}$ & $\begin{array}{l}-4.275 * * * \\
(0.253)\end{array}$ & $\begin{array}{l}-0.253^{\phi} \\
(0.014)\end{array}$ \\
\hline Post CMS CoP $*$ negative report card $*$ highly sensitized & $\begin{array}{l}9.500 * * * \\
(0.571)\end{array}$ & $\begin{array}{l}0.276^{\phi} \\
(0.015)\end{array}$ & $\begin{array}{l}10.516^{* * * *} \\
(0.728)\end{array}$ & $\begin{array}{l}0.342^{\phi} \\
(0.023)\end{array}$ & $\begin{array}{l}3.566^{* * * *} \\
(0.690)\end{array}$ & $\begin{array}{l}0.100^{\phi} \\
(0.018)\end{array}$ \\
\hline Post CMS CoP $*$ negative report card $*$ proportion with diabetes & $\begin{array}{l}-1.040^{* * * *} \\
(0.233)\end{array}$ & $\begin{array}{l}-0.147^{\phi} \\
(0.035)\end{array}$ & $\begin{array}{l}-1.718^{* * * *} \\
(0.281)\end{array}$ & $\begin{array}{l}-0.270^{\phi} \\
(0.043)\end{array}$ & $\begin{array}{l}0.790 * * \\
(0.327)\end{array}$ & $\begin{array}{l}0.101^{\phi} \\
(0.041)\end{array}$ \\
\hline Observations & \multicolumn{2}{|c|}{164,876} & \multicolumn{2}{|c|}{164,876} & \multicolumn{2}{|c|}{164,876} \\
\hline Log-Likelihood (0) & \multicolumn{2}{|c|}{$-212,087$} & \multicolumn{2}{|c|}{$-212,087$} & \multicolumn{2}{|c|}{$-212,087$} \\
\hline Log-Likelihood & \multicolumn{2}{|c|}{$-167,975$} & \multicolumn{2}{|c|}{$-167,977$} & \multicolumn{2}{|c|}{$-167,971$} \\
\hline
\end{tabular}

Abbreviations- $B M I$ body mass index, ECD expanded criteria donor, CMS Centers for Medicare and Medicaid Services, CoP Conditions of Participation. Standard errors are reported in parentheses. $†$ Marginal effects are estimated using a simulation method similar to the Krinsky, Robb [62] and Krinsky, Robb [63] method used for elasticity calculations. We take 1000 draws from the parameter distribution and estimate the change in probability resulting from a $1 \%$ change in the covariates for continuous variables and a shift from 0 to 1 for binary variables in the regression. Our results allow to construct $95 \%$ confidence intervals that we use to estimate statistical significance. Inference: $* * * p<0.01, * * p<0.05, * p<0.1 ;{ }^{\phi}$ indicates statistically significant at $>95 \%$ level 
Table 11 The effect of regulatory-binding report cards on patient selection of a transplant center: second stage of the sorting equilibrium model with risk factor interaction terms

75th Percentile of Distances Traveled (74-Mile Buffer)

\begin{tabular}{|c|c|c|c|}
\hline Variable & $\begin{array}{l}\text { Either Graft or Patient } \\
\text { Survival Rate } \\
\text { Coeff. }\end{array}$ & $\begin{array}{l}\text { Graft Survival Rate } \\
\text { Coeff. }\end{array}$ & $\begin{array}{l}\text { Patient Survival Rate } \\
\text { Coeff. }\end{array}$ \\
\hline Constant & $\begin{array}{l}9.761 * * * \\
(1.234)\end{array}$ & $\begin{array}{l}9.804 * * * \\
(1.237)\end{array}$ & $\begin{array}{l}9.788 * * * \\
(1.229)\end{array}$ \\
\hline Average age of patients & $\begin{array}{l}-5.242^{* *} \\
(2.279)\end{array}$ & $\begin{array}{l}-5.345^{* *} \\
(2.284)\end{array}$ & $\begin{array}{l}-5.108^{* *} \\
(2.267)\end{array}$ \\
\hline Proportion of white patients & $\begin{array}{l}1.701 * * * \\
(0.343)\end{array}$ & $\begin{array}{l}1.699 * * * \\
(0.345)\end{array}$ & $\begin{array}{l}1.655 * * * \\
(0.342)\end{array}$ \\
\hline Proportion of black patients & $\begin{array}{l}-0.489 \\
(0.327)\end{array}$ & $\begin{array}{l}-0.513^{* * * *} \\
(0.327)\end{array}$ & $\begin{array}{l}-0.527 \\
(0.325)\end{array}$ \\
\hline Proportion of female patients & $\begin{array}{l}2.713 * * * \\
(0.893)\end{array}$ & $\begin{array}{l}2.700 * * * \\
(0.896)\end{array}$ & $\begin{array}{l}2.651 * * * \\
(0.888)\end{array}$ \\
\hline Average BMI of patients & $\begin{array}{l}-13.255^{* * * *} \\
(3.058)\end{array}$ & $\begin{array}{l}-13.189 * * * \\
(3.062)\end{array}$ & $\begin{array}{l}-13.455^{* * * *} \\
(3.041)\end{array}$ \\
\hline ECD transplants in past year & $\begin{array}{l}6.808 * * * \\
(0.681)\end{array}$ & $\begin{array}{l}6.702 * * * \\
(0.683)\end{array}$ & $\begin{array}{l}6.815^{* * *} \\
(0.677)\end{array}$ \\
\hline Proportion of highly sensitized patients & $\begin{array}{l}-3.400^{* * * *} \\
(1.281)\end{array}$ & $\begin{array}{l}-3.267^{* *} \\
(1.284)\end{array}$ & $\begin{array}{l}-3.217^{* *} \\
(1.275)\end{array}$ \\
\hline Proportion of patients with diabetes & $\begin{array}{l}-7.907 * * * \\
(0.730)\end{array}$ & $\begin{array}{l}-8.026^{* * * *} \\
(0.733)\end{array}$ & $\begin{array}{l}-7.843^{* * * *} \\
(0.727)\end{array}$ \\
\hline Annual kidney donors in donation area & $\begin{array}{l}-1.287 * * * \\
(0.062)\end{array}$ & $\begin{array}{l}-1.284 * * * \\
(0.063)\end{array}$ & $\begin{array}{l}-1.297 * * * \\
(0.062)\end{array}$ \\
\hline Negative report card & $\begin{array}{l}-0.003 \\
(0.259)\end{array}$ & $\begin{array}{l}0.023 \\
(0.303)\end{array}$ & $\begin{array}{l}-0.084 \\
(0.321)\end{array}$ \\
\hline Post CMS CoP & $\begin{array}{l}-1.216^{* * *} \\
(0.176)\end{array}$ & $\begin{array}{l}-1.176^{* * *} \\
(0.174)\end{array}$ & $\begin{array}{l}-1.245^{* * *} \\
(0.172)\end{array}$ \\
\hline Negative report card*post CMS CoP & $\begin{array}{l}0.119 \\
(0.360)\end{array}$ & $\begin{array}{l}-0.192 \\
(0.419)\end{array}$ & $\begin{array}{l}0.737 \\
(0.452)\end{array}$ \\
\hline Shares $(\rho) \dagger$ & $\begin{array}{l}-36.079^{* *} \\
(14.068)\end{array}$ & $\begin{array}{l}-34.114 * * \\
(14.388)\end{array}$ & $\begin{array}{l}-34.574 * * \\
(13.900)\end{array}$ \\
\hline Observations & 3294 & 3294 & 3294 \\
\hline R-squared & 0.337 & 0.337 & 0.338 \\
\hline
\end{tabular}

Abbreviations- $B M I$ body mass index, ECD expanded criteria donor, $C M S$ Centers for Medicare and Medicaid Services, CoP Conditions of Participation. Standard errors are reported in parentheses. $\dagger$ The parameter $\rho$ is the share of patients that have selected a particular transplant center in a particular time period and the corresponding coefficient reported captures the degree of congestion $(-)$ or agglomeration $(+)$. Inference: $* * * p<0.01, * *$ $p<0.05, * p<0.1$ 


\section{References}

1. Marshall MN, Shekelle PG, Davies HT, Smith PC (2003) Public reporting on quality in the United States and the United Kingdom. Health Aff 22(3):134-148

2. Centers for Medicare and Medicaid Services (2007) Medicare Program; Hospital Conditions of Participation: Requirements for Approval and Re-Approval of Transplant Centers to Perform Organ Transplants. Federal Register, pp 15197-15280

3. Whitlock J (2019) How to Get on the Waiting List for an Organ Transplant. https://www.verywellhealth.com/organ-transplantwaiting-list-requirements-3156951. Accessed 08/28/2019 2019

4. Sehgal AR (2017) Should transplant referral be a clinical performance measure? J Am Soc Nephrol 28(3):721-723. https://doi.org/ 10.1681/ASN.2016111169

5. Sullivan C, Leon JB, Sayre SS, Marbury M, Ivers M, Pencak JA et al (2012) Impact of navigators on completion of steps in the kidney transplant process: a randomized, controlled trial. Clin J Am Soc Nephrol 7(10):1639-1645

6. Dageforde LA, Box A, Feurer ID, Cavanaugh KL (2015) Understanding patient barriers to kidney transplant evaluation. Transplantation. 99(7):1463-1469

7. Jones D, You Z, Kendrick JB (2018) Racial/ethnic differences in barriers to kidney transplant evaluation among hemodialysis patients. Am J Nephrol 47(1):1-7

8. Kasiske BL, Wey A, Salkowski N, Zaun D, Schaffhausen CR, Israni AK, Snyder JJ (2019) Seeking new answers to old questions about public reporting of transplant program performance in the United States. Am J Transplant 19(2):317-323

9. Howard DH (ed) (2008) Hospital quality and selective contracting: evidence from kidney transplantation. Forum for Health Economics \& Policy. De Gruyter

10. Evans RW (1992) Public and private insurer designation of transplantation programs. Transplantation. 53(5):1041-1046

11. United States Renal Data System (2018) 2018 USRDS Annual Data Report: Epidemiology of Kidney Disease in the United States: National Institutes of Health, National Institute of Diabetes and Digestive and Kidney Diseases, Bethesda, MD

12. Schneider EC, Epstein AM (1996) Influence of cardiac-surgery performance reports on referral practices and access to care- a survey of cardiovascular specialists. N Engl J Med 335(4):251-256

13. Waterman AD, Peipert JD, Hyland SS, McCabe MS, Schenk EA, Liu J (2013) Modifiable patient characteristics and racial disparities in evaluation completion and living donor transplant. Clin J Am Soc Nephrol 8(6):995-1002

14. Waterman AD, Peipert JD, Goalby CJ, Dinkel KM, Xiao H, Lentine KL (2015) Assessing transplant education practices in dialysis centers: comparing educator reported and Medicare data. Clin J Am Soc Nephrol 10(9):1617-1625

15. Kucirka LM, Grams M, Balhara KS, Jaar BG, Segev DL (2012) Disparities in provision of transplant information affect access to kidney transplantation. Am J Transplant 12(2):351-357

16. Alexander GC, Sehgal AR (1998) Barriers to cadaveric renal transplantation among blacks, women, and the poor. JAMA. 280(13): $1148-1152$

17. Schold JD, Gregg JA, Harman JS, Hall AG, Patton PR, MeierKriesche H-U (2011) Barriers to evaluation and wait listing for kidney transplantation. Clin J Am Soc Nephrol 6(7):1760-1767

18. Ouayogodé MH (2019) Quality-based ratings in medicare and trends in kidney transplantation. Health Serv Res 54(1):106-116. https://doi.org/10.1111/1475-6773.13098

19. Hawryluk M (2014) Patients denied transplants as donor organs are discarded. https://www.bendbulletin.com/lifestyle/health/patientsdenied-transplants-as-donor-organs-are-discarded/article 350ffb34-0f80-5835-bfdd-5be6ca9f1d8a.html. Accessed 02/18/ 20202020

20. Schold JD, Buccini LD, Phelan MP, Jay CL, Goldfarb DA, Poggio ED, Sedor JR (2017) Building an ideal quality metric for ESRD health care delivery. Clin J Am Soc Nephrol 12(8):1351-1356

21. Madison K (2009) The law and policy of health care quality reporting. Campbell Law Rev 31:215

22. Dranove D, Kessler D, McClellan M, Satterthwaite M (2003) Is more information better? The effects of "report cards" on health care providers. J Polit Econ 111(3):555-588

23. Schold JD, Arrington CJ, Levine G (2010) Significant alterations in reported clinical practice associated with increased oversight of organ transplant center performance. Prog Transplant 20(3):279287

24. McFadden D (1973) Conditional logit analysis of qualitative choice behavior. In: Zarembka P (ed) Frontiers in econometrics. New York: Wiley, Academic Press, pp 105-42

25. Berry S, Levinsohn J, Pakes A (1995) Automobile prices in market equilibrium. Econometrica 63(4):841-890

26. Hicks RL, Horrace WC, Schnier KE (2012) Strategic substitutes or complements? The game of where to fish. J Econ 168(1):70-80

27. Kuminoff NV, Smith VK, Timmins C (2013) The new economics of equilibrium sorting and its transformational role for policy evaluation. J Econ Lit 51(4):1007-1062

28. Porell FW, Adams EK (1995) Hospital choice models: a review and assessment of their utility for policy impact analysis. Med Care Res Rev 52(2):158-195

29. Pauly MV (2004) Competition in medical services and the quality of care: concepts and history. Int J Health Care Finance Econ 4(2): $113-130$

30. Organ Procurement and Transplantation Network. History and NOTA. 2016

31. Katz ML (2013) Provider competition and healthcare quality: more bang for the buck? Int J Ind Organ 31(5):612-625

32. Gravelle H, Sivey P (2010) Imperfect information in a qualitycompetitive hospital market. J Health Econ 29(4):524-535

33. Varkevisser M, van der Geest SA, Schut FT (2012) Do patients choose hospitals with high quality ratings? Empirical evidence from the market for angioplasty in the Netherlands. J Health Econ 31(2): 371-378

34. Bundorf MK, Chun N, Goda GS, Kessler DP (2009) Do markets respond to quality information? The case of fertility clinics. J Health Econ 28(3):718-727

35. Hanson K, Yip WC, Hsiao W (2004) The impact of quality on the demand for outpatient services in Cyprus. Health Econ 13(12): $1167-1180$

36. Howard DH, Kaplan B (2006) Do report cards influence hospital choice? The case of kidney transplantation. INQUIRY 43(2):150 159

37. Mukamel DB, Weimer DL, Zwanziger J, Gorthy S-FH, Mushlin AI (2004) Quality report cards, selection of cardiac surgeons, and racial disparities: a study of the publication of the New York State Cardiac Surgery Reports. INQUIRY 41(4):435-446

38. Pope DG (2009) Reacting to rankings: evidence from "America's best hospitals". J Health Econ 28(6):1154-1165

39. Wedig GJ, Tai-Seale M (2002) The effect of report cards on consumer choice in the health insurance market. J Health Econ 21(6): 1031-1048

40. Epstein AJ (2010) Effects of report cards on referral patterns to cardiac surgeons. J Health Econ 29(5):718-731

41. Wang J, Hockenberry J, Chou S-Y, Yang M (2011) Do bad report cards have consequences? Impacts of publicly reported provider quality information on the CABG market in Pennsylvania. J Health Econ 30(2):392-407 
42. Dafny L, Dranove D (2008) Do report cards tell consumers anything they don't already know? The case of Medicare HMOs. RAND J Econ 39(3):790-821

43. Mukamel DB, Mushlin AI, Weimer D, Zwanziger J, Parker T, Indridason I (2000) Do quality report cards play a role in HMOs' contracting practices? Evidence from New York state. Health Serv Res 35(1 Pt 2):319-332

44. Romano PS, Zhou H (2004) Do well-publicized risk-adjusted outcomes reports affect hospital volume? Med Care 42(4):367-377

45. Cutler DM, Huckman RS, Landrum MB (2004) The role of information in medical markets: an analysis of publicly reported outcomes in cardiac surgery National Bureau of Economic Research

46. Dranove D, Sfekas A (2008) Start spreading the news: a structural estimate of the effects of New York hospital report cards. J Health Econ 27(5):1201-1207

47. Mukamel DB, Mushlin AI (1998) Quality of care information makes a difference: an analysis of market share and price changes after publication of the New York state cardiac surgery mortality reports. Med Care 36(7):945-954

48. Geweke J, Gowrisankaran G, Town RJ (2003) Bayesian inference for hospital quality in a selection model. Econometrica. 71(4): 1215-1238

49. Bayer P, Timmins C (2005) On the equilibrium properties of locational sorting models. J Urban Econ 57(3):462-477

50. Bayer P, Timmins C (2007) Estimating equilibrium models of sorting across locations. Econ J 117(518):353-374

51. Berry ST (1994) Estimating discrete-choice models of product differentiation. RAND J Econ 25(2):242-262

52. Jakus P, Shaw WD (1997) Congestion at recreation areas: empirical evidence on perceptions, mitigating behaviour and management preferences. J Environ Manag 50(4):389-401

53. Timmins C, Murdock J (2007) A revealed preference approach to the measurement of congestion in travel cost models. J Environ Econ Manag 53(2):230-249

54. Tay A (2003) Assessing competition in hospital care markets: the importance of accounting for quality differentiation. RAND J Econ 34(4):786-814

55. Gowrisankaran G, Town RJ (2003) Competition, payers, and hospital quality. Health Serv Res 38(6p1):1403-1422

56. Health Resources and Services Administration U.S. Department of Health and Human Services (2008) Partnering with your transplant team: the patient's guide to transplantation. In: Healthcare Systems Bureau DoT, editor

57. Shetty A, Friedewald JJ (2015) Kidney transplantation in the elderly. Amerian Society of Nephrology Kidney News2015 August

58. Segev DL, Simpkins CE, Thompson RE, Locke JE, Warren DS, Montgomery RA (2008) Obesity impacts access to kidney transplantation. J Am Soc Nephrol 19(2):349-355

59. Metzger RA, Delmonico FL, Feng S, Port FK, Wynn JJ, Merion RM (2003) Expanded criteria donors for kidney transplantation. Am J Transplant 3(s4):114-125

60. Montefiore Medical Center (2020) Highly sensitized patients. https://www.montefiore.org/nephrology-kidney-transplantprogram-highly-sensitized-patients. Accessed 5/29/2020 2020
61. Krinsky I, Robb AL (1986) On approximating the statistical properties of elasticities. Rev Econ Stat 68:715-719

62. Krinsky I, Robb A (1990) On approximating the statistical properties of Elasticities: a correction. Rev Econ Stat 72(1):189-190

63. Health Resources and Services Administration U.S. Department of Health and Human Services (2012) Find an Organ Transplant Center. https://opotxfind.hrsa.gov/

64. United States Census Bureau (2012) TIGER/Line Shapefiles. 2012. https://www.census.gov/geographies/mapping-files/time-series/ geo/tiger-line-file.html

65. Organ Procurement and Transplantation Network (2017) National Data

66. Roberts J, Nedungadi P (1995) Studying consideration in the consumer decision process: progress and challenges. Int J Res Mark 12(1):3-7

67. Shocker AD, Ben-Akiva M, Boccara B, Nedungadi P (1991) Consideration set influences on consumer decision-making and choice: issues, models, and suggestions. Mark Lett 2(3):181-197

68. Organ Procurement and Transplantation Network (2015) Organ Datasource. https://optn.transplant.hrsa.gov/data/organdatasource/. 2015

69. Stith SS, Hirth RA (2016) The effect of performance standards on health care provider behavior: evidence from kidney transplantation. J Econ Manag Strategy 25(4):786-825

70. White SL, Zinsser DM, Paul M, Levine GN, Shearon T, Ashby VB, Magee JC, Li Y, Leichtman AB (2015) Patient selection and volume in the era surrounding implementation of Medicare conditions of participation for transplant programs. Health Serv Res 50(2): 330-350

71. Salkowski N, Snyder J, Zaun D, Leighton T, Edwards E, Israni A et al (2014) A scientific registry of transplant recipients bayesian method for identifying underperforming transplant programs. Am J Transplant 14(6):1310-1317

72. Scientific Registry for Transplant Recipients (2016) ProgramSpecific Reports. https://www.srtr.org/reports-tools/programspecific-reports/

73. Centers for Medicare and Medicaid Services (2016) Solid Transplant Programs - Outcome Thresholds - Revised Guidelines

74. Jay C, Schold JD (2017) Measuring transplant center performance: the goals are not controversial but the methods and consequences can be. Curr Transplant Rep 4(1):52-58

75. American Society of Transplant Surgeons (2020) Transplant Capacity and Testing in the COVID-19 Era. https://asts.org/ advocacy/covid-19-resources/asts-covid-19-strike-force/ transplant-capacity-and-testing\#.XtGuTIVKipo. Accessed 05/29/ 20202020

76. Boyarsky BJ, Chiang TPY, Werbel WA, Durand CM, Avery RK, Getsin SN et al (2020) Early impact of COVID-19 on transplant center practices and policies in the United States. Am J Transplant 20:1809-1818

Publisher's note Springer Nature remains neutral with regard to jurisdictional claims in published maps and institutional affiliations. 